\title{
Integrated chronostratigraphy of Proterozoic-Cambrian boundary beds in the western Anabar region, northern Siberia
}

\author{
ALAN J. KAUFMAN*, ANDREW H. KNOLL*, MIKHAIL A. SEMIKHATOV†, \\ JOHN P. GROTZINGER $\ddagger$, STEIN B. JACOBSEN§ \& WILLIAM ADAMS॥ \\ * Botanical Museum, Harvard University, Cambridge MA 02138, USA \\ $\dagger$ Geological Institute, Russian Academy of Sciences, Moscow 109107, Russia \\ $\ddagger$ Department of Earth, Atmospheric, and Planetary Sciences, Massachusetts Institute of Technology, Cambridge MA 02139, USA \\ $\S$ Department of Earth and Planetary Sciences, Harvard University, Cambridge MA 02138, USA \\ II Department of Earth Sciences, Dartmouth College, Hanover NH 03755, USA
}

(Received 22 June 1995; accepted 5 February 1996)

\begin{abstract}
Carbonate-rich sedimentary rocks of the western Anabar region, northern Siberia, preserve an exceptional record of evolutionary and biogeochemical events near the Proterozoic/Cambrian boundary. Sedimentologically, the boundary succession can be divided into three sequences representing successive episodes of late transgressive to early highstand deposition; four parasequences are recognized in the sequence corresponding lithostratigraphically to the Manykai Formation. Small shelly fossils are abundant and include many taxa that also occur in standard sections of southeastern Siberia. Despite this coincidence of faunal elements, biostratigraphic correlations between the two regions have been controversial because numerous species that first appear at or immediately above the basal Tommotian boundary in southeastern sections have first appearances scattered through more than thirty metres of section in the western Anabar. Carbon- and $\mathrm{Sr}$-isotopic data on petrographically and geochemically screened samples collected at one- to two-metre intervals in a section along the Kotuikan River, favour correlation of the Staraya Reckha Formation and most of the overlying Manykai Formation with sub-Tommotian carbonates in southeastern Siberia. In contrast, isotopic data suggest that the uppermost Manykai Formation and the basal $26 \mathrm{~m}$ of the unconformably overlying Medvezhya Formation may have no equivalent in the southeast; they appear to provide a sedimentary and palaeontological record of an evolutionarily significant time interval represented in southeastern Siberia only by the sub-Tommotian unconformity. Correlations with radiometrically dated horizons in the Olenek and Kharaulakh regions of northern Siberia suggest that this interval lasted approximately three to six million years, during which essentially all 'basal Tommotian' small shelly fossils evolved.
\end{abstract}

\section{Introduction}

During the past three decades, the general pattern of Early Cambrian faunal succession has been established (Rozanov et al. 1969; Qian \& Bengtson, 1989; Repina \& Rozanov, 1992; Lipps \& Signor, 1992); however, the biostratigraphic detail necessary for precise interbasinal correlation remains a subject for debate, especially for the uppermost part of the Vendian System and the lowermost Cambrian Nemakit-Daldynian and Tommotian stages. Traditionally, the correlation of Proterozoic/Cambrian boundary successions has centered on skeletonized invertebrates, especially archaeocyathids and the small shelly fossils (SSF) common in carbonate facies, but problems of taxonomy, taphonomy and facies control hamper biostratigraphic interpretation (Rozanov, 1982; Qian \& Bengtson, 1989; Repina \& Rozanov, 1992; Landing, 1992; Khomentovsky \& Karlova, 1993, 1994). In the absence of unambiguous global zonation and correlations, a detailed reconstruction of evolutionary pattern during the early part of the Cambrian explosion remains beyond our grasp.

Given continuing disagreement about zonation and correlations and the need of a framework for ordering evolutionary events that is independent of the organisms under consideration, there has been growing interest in additional means of correlating latest Proterozoic and basal Cambrian successions. Trace fossils have loomed large in some zonations, especially in siliciclastic successions (Crimes, 1987; Narbonne \& Myrow, 1988; Fedonkin, 1990), and ichnostratigraphy attained critical importance in the choice of a global stratotype section and point (GSSP) for the initial boundary of the Cambrian Period (Narbonne et al. 1987; Landing, 1994; Brasier, Cowie \& Taylor, 1994). Although trace fossils are made by metazoans, the animals that make them are not well represented by skeletons. Thus, terminal Proterozoic/basal Cambrian zonation based on ichnofaunal succession fulfills the criterion of essential independence from the SSF record; however, early ichnofossils share with skeletons unresolved problems of taxonomy, taphonomy and facies dependence.

Acritarchs diversified across the Proterozoic/Cambrian boundary in concert with invertebrates, providing the potential for a biostratigraphic zonation that is truly independent of animal fossils (Volkova, 1968; Volkova et al. 1979, 1983; Moczydłowska, 1991). Basal Cambrian acritarch zones were developed in siliciclastic succes- 


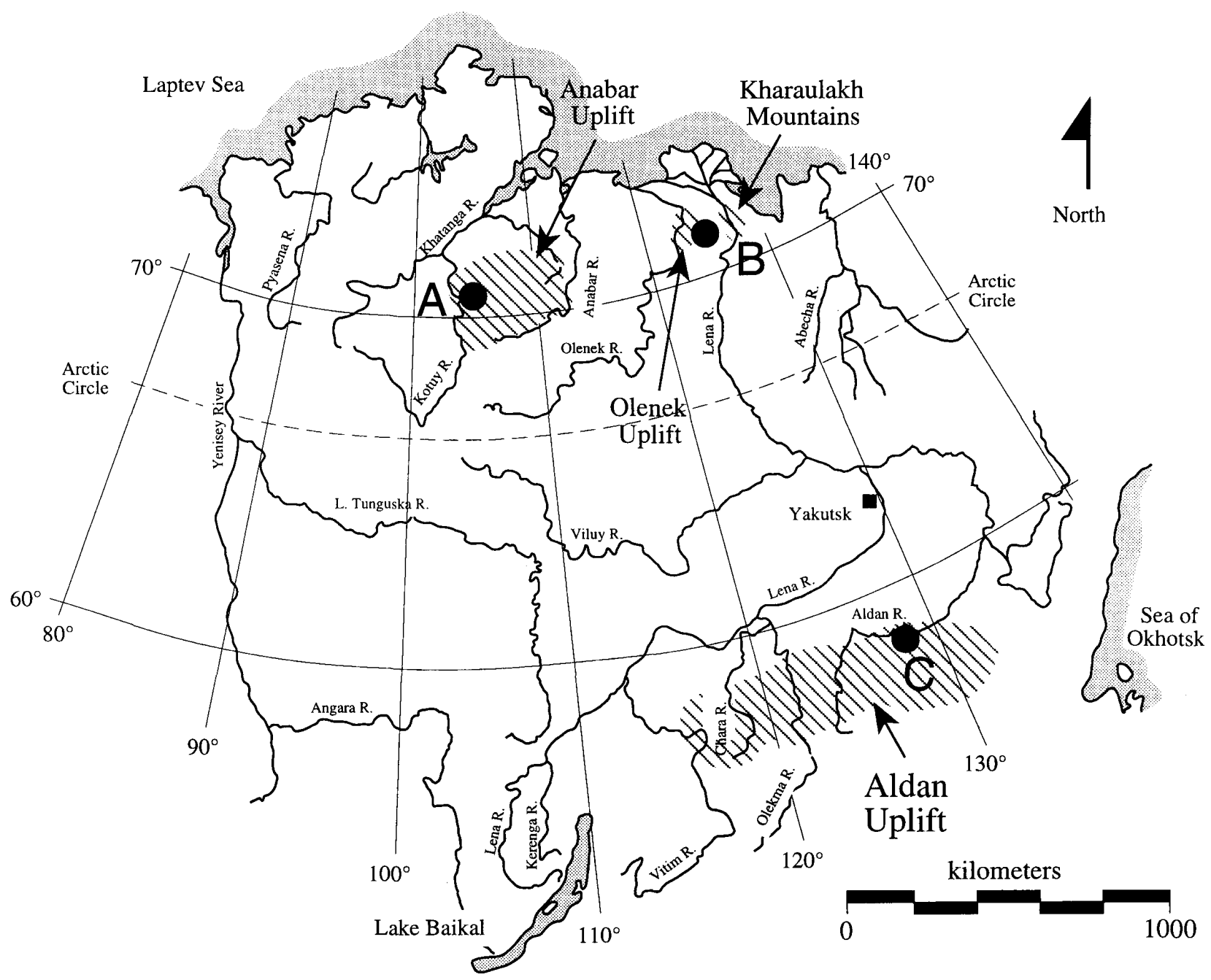

Figure 1. Map showing the locations of successions mentioned in the text. A denotes the Kotuikan River section; B marks the Olenek Uplift section measured along the Khorbusuonka River (site of the U-Pb date on a basal Nemakit-Daldyn volcanic breccia reported by Bowring et al. 1993); C marks the basal Tommotian stratotype section and point.

sions of the East European Platform, but they have been difficult to apply in the carbonate-dominated standard sections of the Lower Cambrian in Siberia, where acritarchs occur sporadically and, with few exceptions, display limited diversity (Rozanov et al. 1969). Recent discoveries of diverse Early Cambrian acritarchs in Siberian sections point the way toward interfacies correlation (Vidal, Moczydłowska \& Rudavskaya, 1995). Palaeomagnetic reversal stratigraphy may also prove important in boundary correlations (e.g. Kirschvink et al. 1991), but available data are limited.

Chemostratigraphy based on the isotopic compositions of carbon and (to a lesser extent) strontium in marine carbonates has been shown to be effective in the correlation of terminal Proterozoic (Kaufman \& Knoll, 1995, and references cited therein) and Early Cambrian (Kirschvink et al. 1991; Magaritz et al. 1991; Brasier, Khomentovsky \& Corfield, 1993; Brasier et al. 1994b) carbonate-bearing successions. Given their amplitude and repeated occurrence, $\mathrm{C}$-isotopic excursions, in particular, show great potential for resolving important questions of correlation among successions that document the initial diversification of animals. Reliable stratigraphic (or biogeochemical) interpretation of isotopic data requires that samples be collected at small stratigraphic intervals and evaluated using a battery of petrographic and geochemical techniques designed to detect diagenetic alteration. In the absence of such tests, the relationship between measured isotopic abundances and depositional values that have stratigraphic significance cannot be known. The problem is significant in terminal Proterozoic successions (Kaufman \& Knoll, 1995) and is exacerbated in Cambrian carbonates, which are bioturbated and contain skeletons not necessarily precipitated in isotopic equilibrium with sea-water (Grant, 1992). Because the terminal Proterozoic and Early Cambrian C-isotopic record contains repeated excursions of broadly similar magnitude, chemostratigraphic interpretation must be anchored by biostratigraphy.

The terminal Proterozoic/basal Cambrian section exposed along the Kotuikan River in the Anabar Uplift, northern Siberia, provides a good test of the capacity of 
isotopic data to resolve problems of boundary-interval correlation (Fig. 1). This largely carbonate section preserves an exceptionally complete sedimentary record of terminal Proterozoic (Upper Vendian) and basal Cambrian time, contains diverse SSF assemblages, includes the stratotype of the pre-Tommotian NemakitDaldynian Stage, was never deeply buried (based on the colour of organic-walled microfossils), and can be correlated by means of bio-, chemo- and lithostratigraphy to other northern Siberian sections that contain well-dated volcanic rocks (Bowring et al. 1993). The western Anabar section has also played an important role in the development of the concept of the Yudomian as the Siberian correlative of the Vendian System (Zhuravleva \& Komar, 1962; Komar, 1966; Semikhatov, Komar \& Serebryakov, 1970).

Despite these features, divergent correlations have been proposed between the western Anabar and the type sections of the Yudomian, Tommotian and Atdabanian intervals in southeastern Siberia. SSFs have been used to support three strikingly different placements of the Nemakit-Daldynian/Tommotian boundary within the Anabar succession (see Section 3.b), and the preTommotian succession in this region has variously been correlated with the whole type Yudomian or a limited part of the Upper Yudomian (Komar, 1966; Rozanov et al. 1969; Semikhatov, Komar \& Serebryakov, 1970; Savitsky, 1975; Khomentovsky, 1976, 1986; Shishkin, 1978; Rozanov, 1982; Semikhatov \& Serebryakov, 1983; Khomentovsky \& Karlova, 1992, 1994). These differing correlations have important implications for the chronostratigraphic resolution of Proterozoic/Cambrian boundary beds and, hence, for understanding both Siberian basin development and the early evolution of animals.

Reconnaissance C-isotopic data for the Anabar succession were published by Pokrovsky \& Vinogradov (1991) and Pokrovsky \& Missarzhevsky (1993); stratigraphic sampling intervals are large, and isotopic determinations were made on whole-rock samples unsupported by geochemical or petrographic data. During a joint expedition in 1992, we measured and sampled the well-studied section near the mouth of the Kotuikan River. Previously, we reported preliminary $\mathrm{C}$-isotopic data and interpretations (Knoll et al. 1995b). Here we present new lithostratigraphic data and sequence stratigraphic interpretations, details of $\mathrm{C}$ - and $\mathrm{Sr}$-isotopic analyses, and a discussion of the chronostratigraphic implications of integrated sequence stratigraphic, palaeontological and chemostratigraphic data.

\section{Lithostratigraphy and sequence stratigraphy}

\section{2.a. Staraya Rechka Formation}

Along the Kotuikan River, the Staraya Rechka Formation is approximately $40 \mathrm{~m}$ thick (Fig. 2). Separated from underlying Riphean units by an angular unconformity (Komar, 1966; Khomentovsky, 1986, 1990), the formation comprises a lithologically complex interleaving of peritidal to shallow subtidal dolostones, evaporites and siliciclastic beds, with no evidence of cyclicity. The formation begins with $0-15 \mathrm{~cm}$ of laterally discontinuous carbonate-pebble conglomerate and minor quartz sandstone (Fig. 2, section 4), overlain successively by stromatolitic dolostone and laminated to rippled dolosiltite and dololutite that grade upward into oolitic grainstone. A small fault juxtaposes rippled dololutite in the hanging wall against the ooid grainstones in the footwall (Fig. 2, sections 3 and 4). The dolosilites are succeeded, in turn, by thickly laminated dololutite containing abundant nodules and lozenge-shaped moulds filled with gypsum (Fig. 2 , section 3), capped by ooid grapestone/packstone with small, symmetrical stromatolites and ripple cross-lamination.

The middle part of the formation consists of interbedded green shale and shaley dololutite, rippled dolosiltite, stromatolitic dolostone and rare quartz sandstone (Fig. 2, section 2). These beds additionally contain an unusual facies consisting of massive dololutite that forms thin beds with tops characterized by 'ridge and furrow' structures. In plan view, these closely resemble strongly elongate stromatolites (see, e.g. Hoffman, 1974), but they show no evidence of lamination in cross-section. Their origin is unclear. The upper Staraya Rechka Formation contains a thick unit of stromatolites overlain by microbially laminated dolostone, a $4 \mathrm{~m}$ unit of massive dololutite containing 'ridge and furrow' structures, and massive dololutite containing abundant gypsum pseudomorphs (Fig. 2, sections 1 and 2).

The Staraya Rechka Formation is interpreted to represent a range of shallow, restricted subtidal to intertidal depositional environments. The presence of evaporites, abundant fine carbonate and siliciclastic sediments, and general lack of stromatolite elongation all support deposition in shallow water devoid of strong currents (Grotzinger, 1986). The presence of thin oolitic beds is consistent with this interpretation; in modern settings like the Persian Gulf, oolites form in restricted peritidal environments where currents are just strong enough to entrain the grains (Freeman, 1962). The Staraya Rechka oolites formed in protected, shallow epicratonic seas located far from the margins of the Siberian craton, in environments of negligible depositional slope. Water depth probably never exceeded a few metres, and the seascape was likely a complex mosaic of shoals and intervening broad lagoons similar to modern Florida Bay (Enos \& Perkins, 1979).

\section{2.b. Manykai Formation}

The Manykai Formation is $88 \mathrm{~m}$ thick along the north bank of the Kotuikan River (Fig. 3). In general, the formation comprises a basal interval of mixed siliciclastic and carbonate rocks that grades upward into relatively pure limestones (and uncommon dolostones). The entire formation is interpreted as a single depositional sequence, bounded by unconformities that coincide with prominent flooding surfaces. The sequence has been sub- 


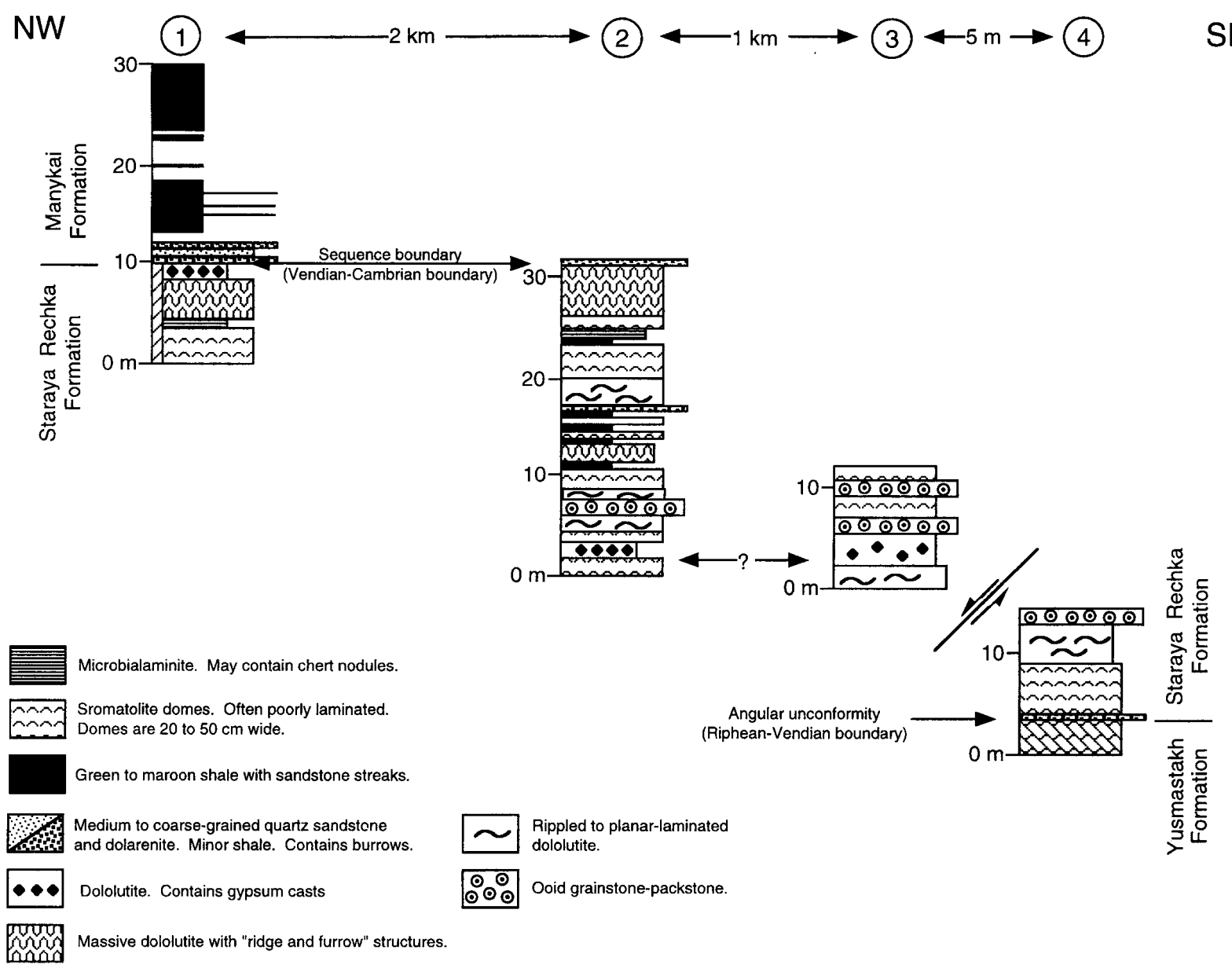

Figure 2. Stratigraphic sections of the Staraya-Rechka Formation along the Kotuikan River. Question mark denotes an uncertainty of c. $\pm 2 \mathrm{~m}$ in correlation between sections 2 and 3 .

divided into four parasequences defined by systematic changes in facies and the partitioning of siliciclastic detritus (Fig. 4).

Parasequence 1 ( $22 \mathrm{~m}$, Fig. 4) contains a basal unit (1.8 m) of medium- to coarse-grained sandstone interbedded with minor shale, dolarenite and microbial laminite (= Bed I of Khomentovsky \& Trofimov, 1980; see also Khomentovsky, 1990). A middle unit, which coincides with Khomentovsky \& Trofimov's Bed II, comprises $18 \mathrm{~m}$ of variegated shale with thin beds and lenses of glauconitic sandstone or dolosiltite in the lower third of the unit. The upper unit $(2 \mathrm{~m}$ thick; = basal Bed III of Khomentovsky \& Trofimov, 1980) is a distinctive interval of ripple-laminated calcarenite and calcisiltite that grades upward into trough cross-bedded Anabarites grainstone/packstone. The base of the grainstone has scoured relief of up to $50 \mathrm{~cm}$. Parasequence 1 is interpreted as a late transgressive or early highstand system tract.

Siliciclastic sediments form only a minor component of parasequence 2 (24 m; Fig. 3). A basal $5 \mathrm{~m}$ unit consists of thin-bedded lime mudstone and calcisiltite, with abundant flat-pebble and edgewise conglomerate. The unit is bioturbated, and its upper part contains nodules developed as diffuse zones of early diagenetic cement around individual burrows. A middle unit, $6 \mathrm{~m}$ thick, comprises a heterogeneous assemblage of interstratified grey shales and thin-bedded lime mudstones. Carbonates contain distinct beds with quasi-planar to hummocky stratification; the bases of these beds may contain intraclasts or resedimented nodules developed as lag deposits. An upper unit, $13 \mathrm{~m}$ thick (Khomentovsky \& Trofimov's Bed IV), is dominated by thick-laminated to thin-bedded calcisiltite and calcarenite with ripple- and small-scale hummocky cross-stratification. Trough cross-bedding is locally developed. As in parasequence 1 , the basal unit of parasequence 2 is interpreted as a transgressive unit deposited during progressive deepening, as shown by the upward increase in shale layers and glauconite. The middle unit records maximum submergence, with mixed shale-carbonate deposition, followed in the upper part by progradation and shallowing to above wave base. These facies are identical to Middle and Upper Cambrian 'ribbon' limestones described from shallow subtidal depositional settings (Demicco, 1983; Markello \& Read, 1981).

Parasequence $3(20 \mathrm{~m})$ begins with a $3.5 \mathrm{~m}$ unit of wavy-bedded lime mudstone with thin shale seams that decrease in abundance upward. Thrombolitic bioherms 


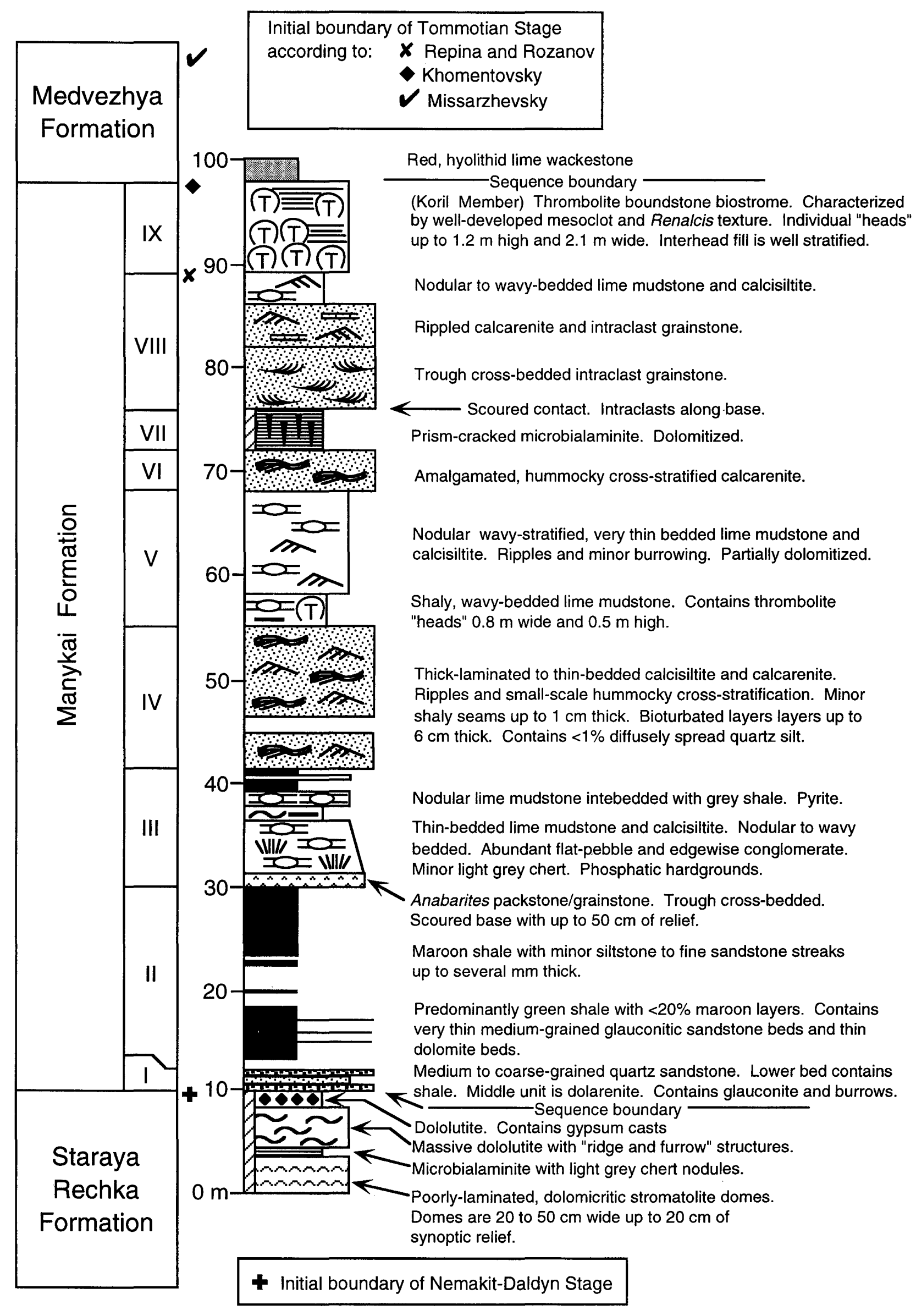

Figure 3. Lithostratigraphy of the Manykai Formation section exposed along the north bank of the Kotuikan River, $c$. 1 km above its confluence with the Kotui River. Roman numerals mark the Beds defined by Khomentovsky \& Trofimov (1980; see also Khomentovsky, 1990). 


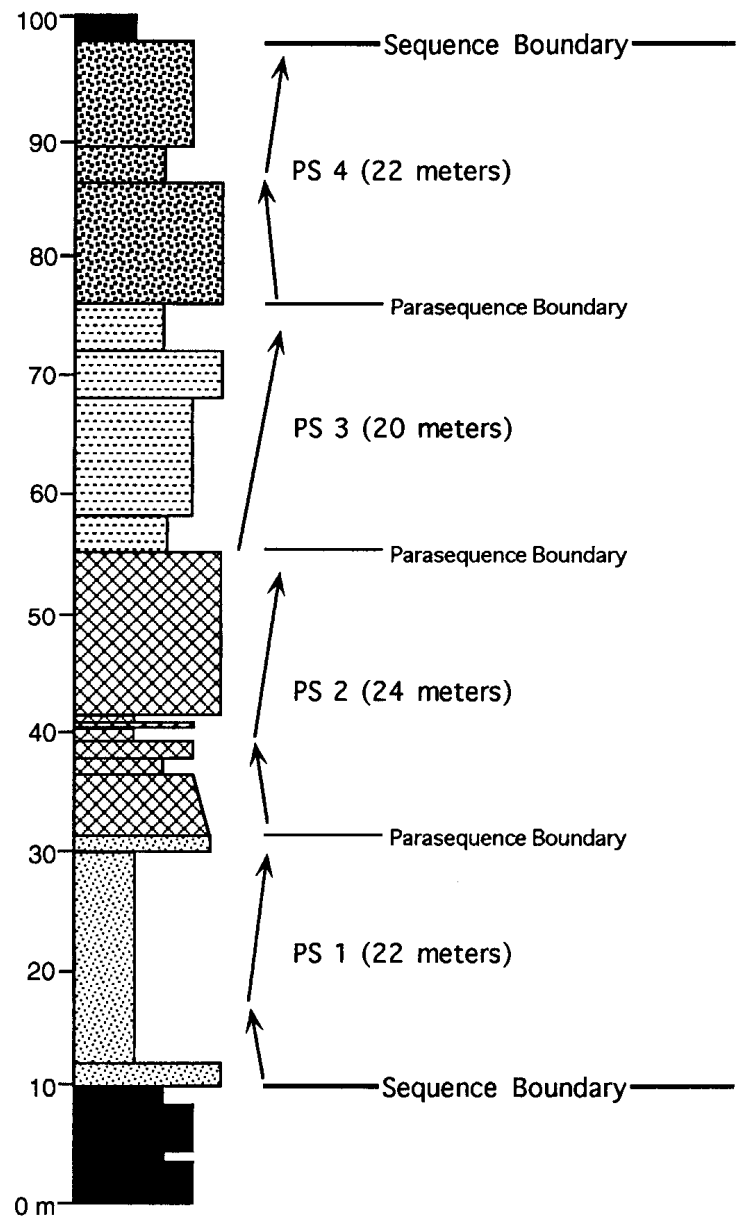

Figure 4. Sequence stratigraphic interpretation of the Manykai Formation, showing the four parasequences identified within the sequence corresponding lithostratigraphically to the formation.

are present in the upper part of the unit (Luchinina, 1989). A second unit, $10 \mathrm{~m}$ thick, consists of nodular to wavy stratified, thin-bedded lime mudstone and calcisiltite. Current and wave-ripple cross-stratification is well developed, and scattered burrows are present. The unit is partially replaced by fine-grained dolomite. The first two units correspond to Bed V of Khomentovsky \& Trofimov (1980), while the third unit, an amalgamated, metre-scale hummocky cross-stratified calcarenite, coincides with Bed VI. The uppermost unit (= Khomentovsky and Trofimov's Bed VII) consists of prism-cracked, microbially laminated dololutite. This parasequence is systematically different from the underlying intervals in that it contains very little siliciclastic detritus, is depositionally asymmetric (lacks transgressive deposits), and shows evidence of shallowing completely to sea-level. The lack of any indicators of extreme exposure (e.g. tepees, karst) is consistent with regional platform aggradation in a highstand system tract.

The uppermost parasequence (parasequence $4 ; 22 \mathrm{~m}$ ) contains no siliciclastic rocks. A basal $10 \mathrm{~m}$ unit consists predominantly of intraclast grainstone, overlying a well-
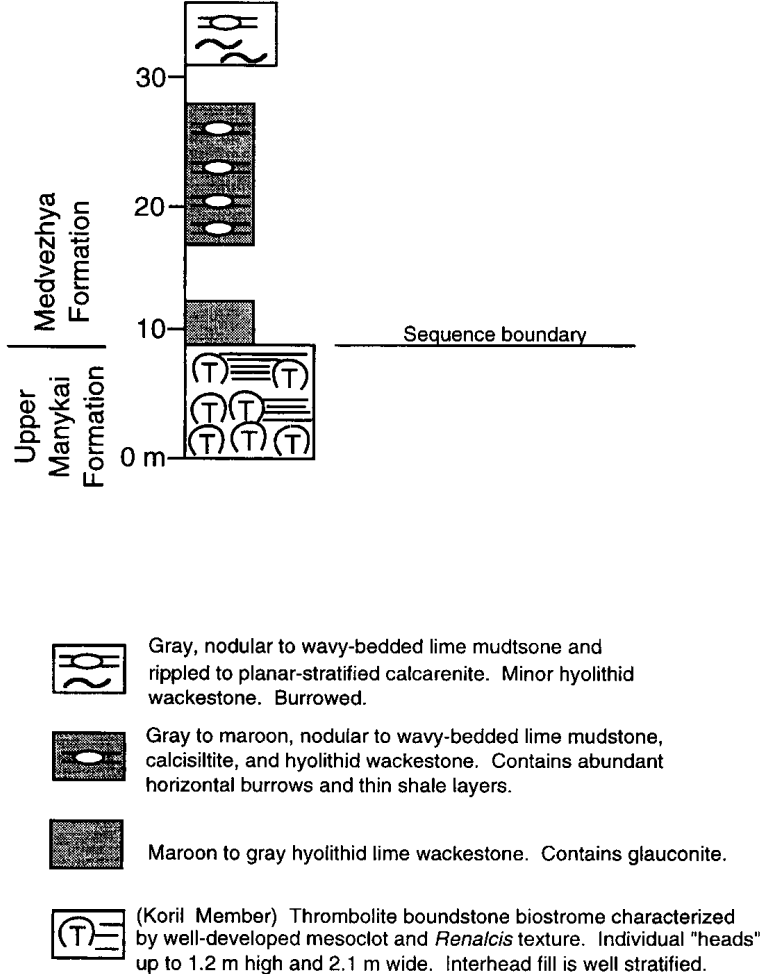

Figure 5. Lithostratigraphy of Medvezhya carbonates sampled in exposures along the Kotuikan River.

developed scoured base. Fine- to medium-grained calcarenites are interstratified with coarser grainstones toward the top. The lower half of the unit is dominated by trough cross-bedding, which is replaced by ripple crossstratification in the upper half. This grades up into a second unit $(4 \mathrm{~m})$ of nodular to wavy-bedded lime mudstone and calcisiltite. The uppermost unit comprises a distinctive thrombolitic boundstone biostrome $(8 \mathrm{~m})$ known as the Koril Member (Bed IX). Thrombolitic textures consist of well-developed mesoclots associated with Renalcis (Luchinina, 1989). Where not amalgamated, bioherms are separated by well-stratified calcarenite and intraclast grainstone. The top of parasequence 4 is marked by a sharp contact with the overlying Medvezhya Formation.

The abundance of grainstone in parasequence 4 suggests deposition in broad shoals swept by strong daily currents (Hine, Wilber \& Neumann, 1981). The lower unit gives way to finer-grained sediments of the middle unit, although deposition is still inferred to have taken place in relatively shallow subtidal conditions, as shown by the abundance of symmetrical, wave-produced ripples (de Raaf, Boersma \& Van Gelder, 1977). Shallowing is supported by the development of the massive, thrombolite biostrome at the top of the parasequence. The sharp contact at the top of parasequence 4 is interpreted as a sequence boundary and flooding surface.

Overall, the Manykai Formation is interpreted as a single, unconformity-bounded depositional sequence con- 
taining four aggradationally-stacked parasequences. Late transgressive to early highstand deposition is favoured by: (1) the lack of systematic changes in parasequence thickness that would accompany long-term changes in accommodation rate; (2) the depositional symmetry in three of the four parasequences, which indicates that parasequence-scale flooding events were not amplified by high long-term accommodation rates; and (3) the absence of tidal flat sediments in three of the four parasequences and/or indicators of subaerial exposure along parasequence boundaries. Finally, late transgressive to early highstand deposition is supported by the upward decrease in the quantity of siliciclastic detritus, which supports progressive coastal onlap.

The unconformable relationship between the Manykai and Staraya Rechka formations, interpreted as a type-II sequence boundary, is regional, extending at least as far as the eastern Anabar Uplift (Khomentovsky, 1990). In contrast, local evidence (exposures along the Kotuikan River) for a sequence boundary at the top of the Manykai Formation is less dramatic. Identification of these surfaces in carbonate-dominated strata typically depends on (1) interpretation of parasequence stacking patterns (Grotzinger, 1986; Montanez \& Osleger, 1993; Read et al. 1986), (2) the presence of indicators of subaerial exposure (Montanez, 1992), and (3) the juxtaposition of palaeoenvironmentally discordant facies (Sarg, 1988). Along the Kotuikan River, the upper boundary of the Manykai Formation lacks strong indications of subaerial exposure; the actual contact is sharp, but no evidence of karst, mouldic porosity or brecciation is seen (Fig. 5). Here, red hyolithid wackestones and mudstones of the basal Medvezhya Formation - which lack evidence for frequent current activity - are juxtaposed against grey, thrombolite biostromes and associated well-stratified, channel grainstones. This suggests a significant flooding event at the top of the Manykai Formation and, at least, a type-II unconformity (cf. Sarg, 1988). Regional observations (Fedorov \& Shishkin, 1984; Missarzhevsky, 1989) show that the Medvezhya Formation and its equivalents form a transgressive blanket over the entire Anabar region, systematically overstepping older strata on the northern slope of the Anabar Uplift. For this reason, we interpret the Manykai/Medvezhya contact as a regionally-extensive type I unconformity (cf. Sloss, 1963).

\section{2.c. The Medvezhya Formation}

In our measured section, typical Medvezhya strata comprise $28 \mathrm{~m}$ of monotonous, maroon to mauve, argillaceous, fossiliferous lime mudstone and wackestone. Locally, SSFs are abundant enough to form packstone lags. Bioturbation is characteristic, and large, simple, bedding-parallel traces are particularly common. These strata represent deposition on an open, shallow-marine carbonate platform. The considerable bioturbation prevents detailed analysis of fairweather stratification, but it is likely that storms resulted in significant reworking of the sea-floor such that fossils were concentrated as lag deposits by winnowing. The Medvezhya Formation represents regional onlap of the Anabar platform, following possible subaerial exposure at the top of the Manykai Formation. Medvezhya carbonates probably accumulated during a highstand in relative sea-level.

Elsewhere in the western Anabar region, comparable Medvezhya facies are up to $60 \mathrm{~m}$ thick (Missarzhevsky, 1989 ), but in our measured section, sugary, yellow dolostones occur above the $28 \mathrm{~m}$ mark. These dolostones are conventionally assigned to the Kyndyn Formation, but Missarzhevsky (1989) shows that they are a regionally variable product of facies and diagenetic change that truncates Medvezhya limestones at different levels in different locations (see also Khomentovsky \& Karlova, 1992). It is, thus, hazardous to think of the Medvezhya-Kyndyn boundary as a time horizon that can be correlated even locally. In the following discussion, we locate fossiliferous and isotopically important horizons in terms of their vertical distance above the base of the Medvezhya Formation.

\section{Biostratigraphy}

Palaeontological investigations over a period of thirty years have provided detailed data on faunal distributions within the Manykai and Medvezhya formations (see references in Missarzhevsky, 1989; Repina \& Rozanov, 1992; Khomentovsky \& Karlova, 1992, 1993, 1994). Critical monographic accounts are not yet available for all of these assemblages, but the present discussion only requires taxonomic consistency between regions.

Khomentovsky \& Karlova $(1992,1993)$ listed the occurrences of 86 invertebrate taxa found regionally in the western Anabar succession ${ }^{1}$. Of these, 65 occur in southeastern Siberian sections, including the Tommotian stratotype. Figure 6 shows the first appearances of these taxa in the western Anabar, along with the zone in which they first occur in the Aldan and/or Uchuro-Maya regions and the summary biostratigraphic interpretations of Khomentovsky \& Karlova (1992, 1993), Repina \& Rozanov (1992) and Missarzhevsky (1989).

All parties agree that the lower Manykai Formation should be assigned to the pre-Tommotian Anabarites trisulcatus zone. There is also agreement that Medvezhya lithologies extend as high as the Atdabanian Pagetiellus anabarus zone some $70 \mathrm{~m}$ above the base of the formation in sections along the Fomich River, $150 \mathrm{~km}$ northeast of our field area. Regionally, trilobites and archaeocyathans indicate that Atdabanian strata begin $40-45 \mathrm{~m}$ above the Manykai/Medvezhya boundary - well above

\footnotetext{
' Khomentovsky \& Karlova (1994) also provide species lists for the eastern Anabar region, but as these are ordered by zone and not by position within measured sections, they comprise biostratigraphic interpretations and cannot be plotted in the same manner as faunal distributions in the western Anabar region and southeastern Siberia.
} 


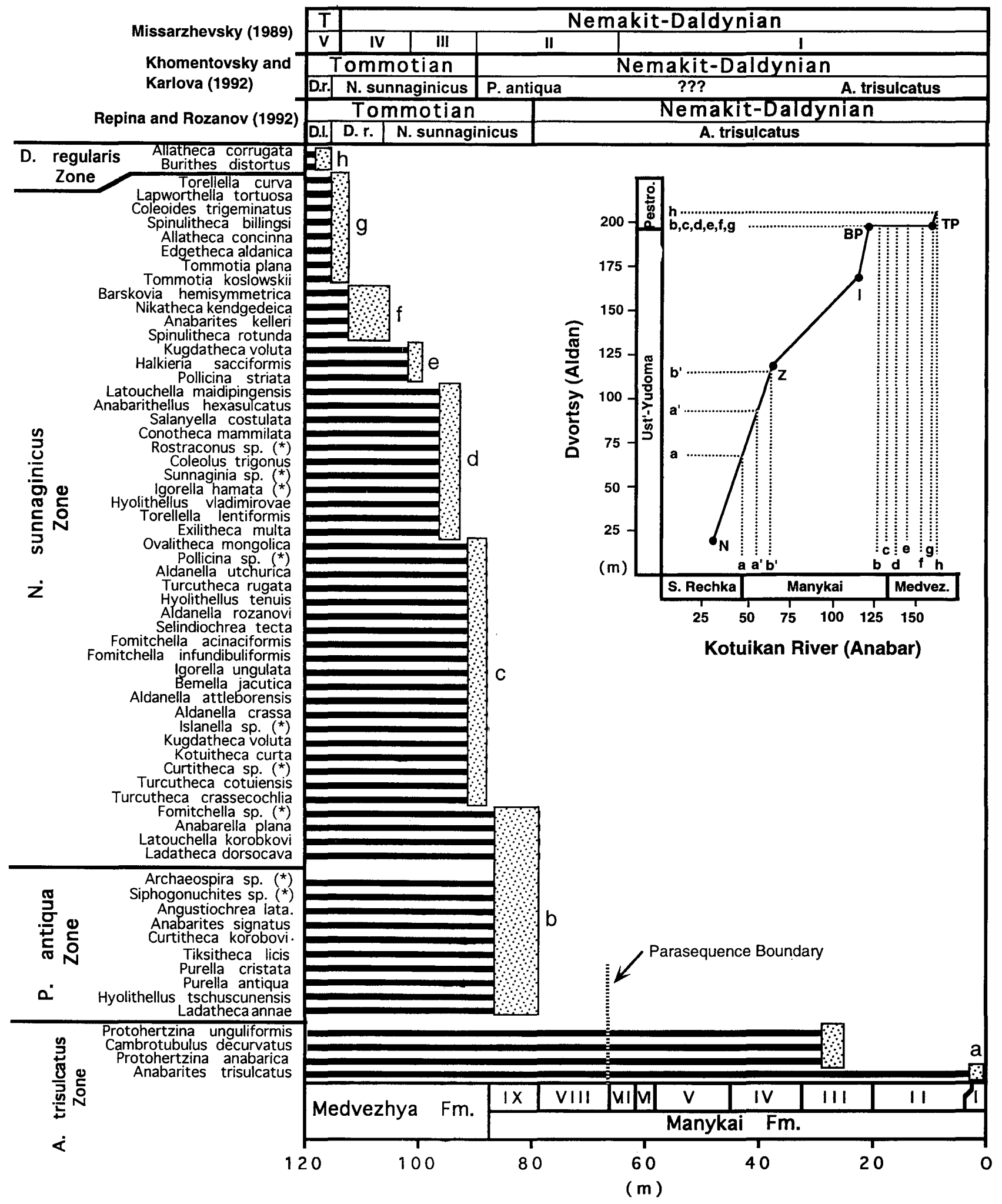

Figure 6. Stratigraphic first appearances in the western Anabar region for taxa that also occur in southeastern Siberia (after Khomentovsky \& Karlova, 1992, 1993). Zone of first appearance in southeastern Siberia is shown on the left; all taxa listed as occurring in the $N$. sunnaginicus Zone have regional first appearances in the southeast that coincide with basal Tommotian onlap. Boxes show interval of first appearance in the western Anabar succession; black lines indicate that taxa persist into younger rocks, though they may not have western Anabar occurrences throughout their known stratigraphic ranges. Biostratigraphic interpretations of Missarzhevsky (1989), Khomentovsky \& Karlova (1992, 1993) and Repina \& Rozanov (1992) are shown across the top. The inset shows a Shaw-type diagram of the Kotuikan River and composite southeastern Siberia sections. N, Z, and I are named C-isotopic peaks (Brasier, Khomentovsky \& Corfield, 1993), as discussed in the text; BP and TP are, respectively, the bottom and top of the Kotuikan interval interpreted as corresponding to the sub-Tommotian unconformity; a and a' indicate first appearances of $A$. trisulcatus Zone faunas in southeastern Siberia and the western Anabar, respectively; $\mathbf{b}$ and $\mathbf{b}$ ' indicate the first appearance of $P$. antiqua Zone faunas in southeastern Siberia and the western Anabar, respectively (with projections onto the other section); c-h indicate the successive horizons at which taxa that first appear in basal Tommotian strata in southeastern Siberia are introduced in the western Anabar area (see main part of diagram); $i$ indicates the first appearance of Burithes distortus, considered an index for the Tommotian D. regularis Zone. Southeastern Siberian data from Khomentovsky \& Karlova (1992, 1993), Repina \& Rozanov (1992), and Brasier, Khomentovsky \& Corfield (1993). 
the top of the interval considered in this paper (Repina \& Rozanov, 1992; Khomentovsky \& Karlova, 1992). In the intervening part of the succession, there is disagreement about placement of the Nemakit-Daldynian/Tommotian boundary and the zonation of boundary beds by means of SSFs (Fig. 6).

Calcified microbes, a limited acritarch flora and scattered trace fossils also occur in the western Anabar succession (Luchinina, 1989; Volkova et al. 1980), but these do not resolve the problems raised by conflicting interpretations of the invertebrate record. Komar (1966), Golovanov (1970) and Semikhatov, Komar \& Serebryakov (1970) used stromatolites in the broad correlation of Staraya Rechka carbonates with other Yudomian deposits, but microbialites do not provide good tests for more refined correlations of terminal Proterozoic rocks.

\section{3.a. Biostratigraphic placement of the initial Tommotian boundary in the western Anabar region: logic}

Any correlation proceeds from a fixed point, defined as a stratigraphic horizon in a type section, to sections distant from the stratotype. In Siberia, the initial boundary of the Tommotian Stage is defined by a point at the base of Bed 8 of the Ust'-Yudoma Formation in the Ulakhan Sulugur section along the Aldan River (Rozanov et al. 1969; Rozanov, 1984). This stratigraphic placement of the boundary is misleading, however; Khomentovsky, Valkov \& Karlova (1990; Khomentovsky \& Karlova, 1992) recognized that the glauconitic lenses in Bed 8 that contain basal Tommotian taxa are karst-filling sediments emplaced during subsequent Pestrotsvet transgression. Regionally, this topologically complex boundary surface (Semikhatov \& Serebryakov, 1983, fig. 41; Khomentovsky \& Karlova, 1993, figs 11, 12) coincides with the first appearance of a diverse invertebrate fossil assemblage. Some 30 taxa occur in lenses of fine-grained glauconitic carbonate that penetrate downward to Bed 8; an additional $c .70$ species of archeocyathans and SSFs occur regionally in basal Pestrotsvet carbonates (Rozanov et al. 1969; Repina \& Rozanov, 1992). In terms of time, then, more than 100 species appear more or less simultaneously in basal Tommotian rocks of southeastern Siberia.

These diverse skeletal assemblages are considered to typify the Nochoroicyathus sunnaginicus Zone (Rozanov et al. 1969; Rozanov, 1984; Repina \& Rozanov, 1992; Khomentovsky \& Karlova, 1992, 1993); however, the base of the Tommotian is not defined by these fossils, and their point of first appearance in a distant section does not by definition indicate precise correlation with the boundary in the stratotype. This consideration is especially important in the case of the Tommotian, because its definitional lower boundary is associated with a karsted unconformity and major facies change (Rozanov et al. 1969; Semikhatov \& Serebryakov, 1983; Moczydłowska \& Vidal, 1988; Khomentovsky \& Karlova, 1992, 1993; Repina \& Rozanov, 1992; Landing, 1994).
In the Aldan region, underlying Ust'-Yudoma strata are dominated by sugary dolostones that (with the exception of the glauconitic lenses of Bed 8 at Ulakhan Sulugur) contain only scattered occurrences of poorly-preserved SSFs in the uppermost few metres of the sections. Better fossil preservation is found in Ust'-Yudoma sections along the Uchur and Dzhanda rivers, some $100 \mathrm{~km}$ east of the Tommotian GSSP (Semikhatov \& Serebryakov, 1983; Khomentovsky \& Karlova, 1992, 1993, 1994), but most published sections for the region show no SSF occurrences in the $c .25 \mathrm{~m}$ immediately below basal Tommotian beds (Khomentovsky \& Karlova, 1993, 1994). Only along the Dzhanda and Selinde rivers do well-preserved SSFs occur within a few metres of the basal Tommotian (basal Pestrostvet) boundary, and these assemblages are of limited diversity (Khomentovsky \& Karlova, 1992, 1993, 1994).

The 65 taxa that both (1) appear first at or near the base of the Tommotian in southern Siberia and (2) occur in the western Anabar have first appearances spread through more than $30 \mathrm{~m}$ of section in the latter (Fig. 6). Clearly, most taxa did not appear simultaneously in the two areas. If the clustered first appearances in southeastern Siberia are interpreted as a record of simultaneous evolution, then the base of the Tommotian in western Anabar can be no higher than the lowermost point of occurrence for any 'basal Tommotian' species. A necessary corollary of this view is that the stratigraphic coincidence, in the Aldan region, of massed fossil appearances, marked facies change, and subtending unconformity is fortuitous.

Biostratigraphic experience in better known parts of the geological record indicates that first appearances distributed through a more-or-less continuous section are more likely to approximate evolutionary pattern than are those clustered at a major facies change or unconformity (e.g. Shaw, 1964). Considering the sedimentological realities of southeastern Siberian sections, all that really can be said of the stratotype region is that when the first beds above the definitional boundary point of the Tommotian Stage accumulated, all c. 100 taxa that typify the $N$. sunnaginicus Zone were already present (Landing, 1994). In this view, the initial Tommotian boundary in western Anabar can be as high as the point at which the last 'basal Tommotian' taxon appears. (Note that this horizon is $c$. 25-27 $\mathrm{m}$ above the base of the Medvezhya Formation whether or not one considers the fossiliferous lenses in Ust'-Yudoma Bed 8 to be karst-fill; Edgetheca aldanica, Coleoloides trigeminatus and Torellella curva all have first appearances in Bed 8 lenses in the GSSP and $>25 \mathrm{~m}$ above the base of the Medvezhya Formation in the Kotuikan area (Fig. 6).)

Intermediate boundary placements are possible, but any such placement requires that one accept some taxa as having synchronous first appearances in the two regions while rejecting synchrony in others. This necessitates arbitrary assumptions about individual taxa that cannot be justified on the basis of existing palaeontological data. 


\section{3.b. Biostratigraphic placement of the initial Tommotian boundary in the western Anabar region: practice}

In the Manykai-Medvezhya interval under consideration, Missarzhevsky (1989) recognized five SSF zones (Fig. 6). His lower two zones, encompassing the Manykai Formation, are approximately equivalent to the NemakitDaldynian Anabarites trisulcatus and Purella antiqua zones recognized by Khomentovsky \& Karlova (1992, 1993); however, Missarzhevky (1989) considered that the Nemakit-Daldynian Stage includes two additional zones that extend upward $25-30 \mathrm{~m}$ into the Medvezhya Formation. He placed the beginning of the Tommotian Stage at the base of his zone V, marked, in his view, by the first appearance of 20 taxa. Many of the taxa that Missarzhevsky (1989) used to define the lower boundary of his zone $\mathrm{V}$ are now known to occur in the lower part of the Medvezhya Formation, where they are associated with other SSF taxa (Khomentovsky \& Karlova, 1992, 1993). None the less, the initial Tommotian boundary favoured by Missarzhevsky (1989) corresponds to the point in the western Anabar section where the last taxa appear that mark the beginning of the Tommotian in its stratotype area.

Khomentovsky \& Karlova (1992, 1993, 1994), in accordance with earlier publications by Khomentovsky, place the base of the Tommotian in western Anabar sections at the lower boundary of the Medvezhya Formation (Fig. 6). Basal Medvezhya beds contain diverse SSFs, most of which have been reported from the $N$. sunnaginicus zone in Aldan and Uchuro-Maya sections. Although this correlation places the base of the Tommotian at the point in the western Anabar succession where the most 'basal Tommotian' taxa first appear, it marks neither the horizon at which the first 'basal Tommotian' fossils enter the record nor the point where the last ones appear.

Repina \& Rozanov (1992) place the lower Tommotian boundary at the point where the first 'basal Tommotian' taxa appear - at the base of Manykai Bed IX (Fig. 6). Thus, as conceived by Repina \& Rozanov (1992), the Tommotian in western Anabar includes strata placed in the Nemakit-Daldynian Purella antiqua Zone (or Zone II) by the preceding authors. Twenty-seven taxa have regional first appearances at this level (Khomentovsky \& Karlova, 1993, 1994), and of these, 14 occur in southeastern Siberia (Fig. 6). Of those that occur in both regions, ten have first appearances in the south that underlie the basal Tommotian boundary by $25 \mathrm{~m}$ or more; four first appear in the southeast in lowermost type Tommotian beds (Repina \& Rozanov, 1992; Khomentovsky \& Karlova, 1993, 1994). Repina \& Rozanov's (1992) preferred correlation receives logical support if the clustered first appearances in the Aldan region are interpreted as evolutionary first appearances unrelated to associated sedimentological changes.

Thus, the three divergent placements of the initial Tommotian boundary in western Anabar reflect the three logical possibilities outlined in the preceding section. Independent means of correlation are necessary to evaluate these alternatives.

\section{3.c. A note on the Nemakit-Daldynian Stage}

Savitsky $(1962,1975)$ was the first to delimit the Nemakit-Daldynian 'horizon' as 'the beds with small hyolithellids' that underlie diverse SSF assemblages in the basal Medvezhya Formation and regarded it as Early Cambrian in age. Later, Khomentovsky (1976) reconsidered the rank of that unit and described it as belonging to the Nemakit-Daldynian Stage, thus assigning it to the uppermost Vendian (Yudomina) in accordance with the view that the Tommotian was the first stage of the Cambrian System (see Rozanov \& Sokolov, 1984, for references). No initial boundary stratotype has been formally defined, and the term has variously been used with reference to time (stage) or lithostratigraphy (horizon). Recent trends in the Russian literature lean towards regarding this unit as a stage.

In so far as the recently-defined base of the Cambrian Period appears to be significantly earlier than the beginning of the Tommotian Stage (see, e.g. Grotzinger $\mathrm{et} \mathrm{al}$. 1995), there is a recognized need to establish a preTommotian basal Cambrian stage, and NemakitDaldynian has increasingly been pressed into service for this purpose. In Savitsky's original usage, the NemakitDaldynian 'horizon' was locally coextensive with the Manykai Formation; however, as a stage the NemakitDaldynian must be defined as beginning at a GSSP and ending at the defined initial boundary of the succeeding Tommotian Stage.

In this paper, we follow Savitsky's intent and subsequent convention in placing the initial boundary of the Nemakit-Daldynian Stage at the base of the Manykai Formation in the section sampled along the Kotuikan River. Here, the initial Nemakit-Daldynian boundary corresponds to the first appearance of SSFs of the Anabarites trisulcatus Zone (Savitsky, 1975; Khomentovsky, 1976; Missarzhevsky, 1989; Khomentovsky \& Karlova, 1992, 1993). This does not necessarily mean, however, that the boundary can be recognized elsewhere by the lowermost occurrences of SSFs. Should the fossils be shown to occur earlier somewhere else - as they do in the Olenek region of northern Siberia (Karlova, 1987; Khomentovsky \& Karlova, 1992, 1993; Knoll et al. $1995 a$; see also the placement of the lowermost SSFs in Iran and Kazakhstan by Brasier et al. 1990, fig. 1) - this does not change the definition of the boundary; it simply means that improved tools are necessary for precise correlation.

\section{Chemostratigraphy of the western Anabar}

\section{4.a. Methods}

Except where precluded by thick siliciclastic units, carbonate samples were collected at $1 \mathrm{~m}$ intervals throughout the Staraya Rechka and Manykai formations and at $2 \mathrm{~m}$ intervals through $28 \mathrm{~m}$ of the Medvezhya Formation. Samples were prepared, screened and analysed according to the procedures described in detail in Kaufman \& Knoll (1995). 


\section{4.b. Elemental and oxygen-isotopic results}

The results of elemental and oxygen-isotopic analyses of carbonate micro-samples are presented in Table 1. All Staraya Rechka carbonates are dolomites, and most have elevated $\mathrm{Mn} / \mathrm{Sr}$. Lower Staraya Rechka carbonates, in particular, are partially silicified and have very high $\mathrm{Mn} / \mathrm{Sr}$; C-isotopic compositions of these samples should be viewed with caution.

Manykai and Medvezhya carbonates are predominantly calcitic, although several samples in the interval between the top of Bed II and the upper Bed VII contain both calcite and dolomite. Within the upper formations, dolomitization is most pronounced immediately adjacent to thick shales or silty/intraclastic horizons. Siliciclastic horizons may have acted as fluid conduits, channelling diagenetic waters through the succession. $\mathrm{Mn} / \mathrm{Sr}$ in the dolomitic samples is slightly higher than in adjacent calcites (which contain virtually no $\mathrm{Mn}$ and have very low $\mathrm{Mn} / \mathrm{Sr}$ ) and oxygen-isotopic compositions are altered to variable extent. There is, however, no systematic relationship between ${ }^{18} \mathrm{O}$ abundances (Table 1 ) and $\mathrm{Mn} / \mathrm{Sr}$ or $\mathrm{Mg} / \mathrm{Ca}$ in the Manykai carbonates. Evidently dolomitization did not result in the systematic resetting of $\delta^{18} \mathrm{O}$ values of these limestones; indeed, with few exceptions, $\delta^{18} \mathrm{O}$ values of the Kotuikan carbonates are remarkably constant. Manykai and Medvezhya carbonate $\delta^{18} \mathrm{O}$ values are remarkably constant while Staraya Rechka dolomites are, on average, enriched in ${ }^{18} \mathrm{O}$ by $2 \%$.

On balance, the degree of alteration determined by elemental and O-isotopic compositions of carbonates in the Manykai and Medvezhya formations is minimal, suggesting that near primary $\delta^{13} \mathrm{C}$ values are retained in most samples. Neither are skeletons abundant in these rocks, minimizing the possibility that 'vital effects' played a significant role in determining $\mathrm{C}$-isotopic compositions (Grant, 1992). Moderately elevated $\mathrm{Mn} / \mathrm{Sr}$ values (5-9) characterize a few dolostones, especially near the base of the section and in parasequence 3 ; however, experience elsewhere indicates that moderate $\mathrm{Mn}$ enrichment is not commonly associated with C-isotopic alteration (Derry, Kaufman \& Jacobsen, 1992; Kaufman \& Knoll, 1995; Knoll, Kaufman \& Semikhatov, 1995). Moreover, stratigraphic trends in this interval are defined by samples that pass all of our screening tests. In the entire Manykai-Medvezhya interval, only four samples are marked by strong ${ }^{18} \mathrm{O}$ depletion; these are interpreted as altered and are not considered further.

\section{4.c. Carbon-isotopic results}

Carbon-isotopic data for the Anabar section are presented in Table 1 and shown graphically in Figure 7. As originally reported by Pokrovsky \& Vinogradov (1991), $\delta^{13} \mathrm{C}$ values for Staraya Rechka dolomites are consistently negative. Values in the lower 22 metres range between +0.1 and $-2.9 \%$, above which they decrease to values as low as $-5.7 \%$; these are the most ${ }^{13} \mathrm{C}$-depleted carbonates in the entire section and, as noted in the previous sec- tion, must be interpreted with caution. However, less altered dolostones in the upper part of the formation also record negative $\delta^{13} \mathrm{C}$ values that increase up-section. Within the upper member, altered and unaltered samples show comparable stratigraphic trends, with altered samples offset toward more negative values (Fig. 7).

The lowermost carbonates in the Manykai Formation are thin dolomicrites interbedded with shale in Bed II. Pokrovsky \& Missarzhevsky (1993) recorded values as low as $-6 \%$ in these dolomites, above which they show a strong increase to values a bit below $+2 \%$ in the lower part of Bed III. Our data also show that Bed II dolomicrites are isotopically light ( -3.6 to $-4.4 \%$ ); however, the low $\delta^{18} \mathrm{O}$ values associated with the more extreme $\delta^{13} \mathrm{C}$ values (Table 1 ) and a high potential for early diagenetic incorporation of isotopically light carbon urges caution in interpretation. Regardless of possible alteration in Bed II dolomites, the unaltered carbonates in lowermost Bed III also have negative $\delta^{13} \mathrm{C}$ values $(-2.0$ to $-1.5 \%$ ) . Thus, the isotopic excursion to moderately positive values (a prominent peak of $+1.8 \%$ ) occurred within Bed III, coincident with the boundary between parasequences 1 and 2, and well above the base of the NemakitDaldynian Stage.

As shown in Figure 7, C-isotopic values show an oscillating but generally increasing trend from the top of Bed III through upper bed VII, where $\delta^{13} \mathrm{C}$ values as high as $+2.5 \%$ form the second largest peak in the succession. This peak is preceded by two troughs with values as low as -4.2 and $-3.7 \%$ confined to the top of Bed III and IV, respectively, and separated by a relatively higher $\delta^{13} \mathrm{C}$ value lower in Bed IV. Within Bed VIII $\delta^{13} \mathrm{C}$ values gradually decrease to $-1.3 \%$ and then increase again toward the top of the bed. A sharp increase to moderately positive values $(+1.6 \%$ ) coincides with the Bed VIII/IX boundary. The sequence boundary that separates Bed IX and the Medvezhya Formation is also marked by a sharp offset in $\delta^{13} \mathrm{C}$ values.

Limestones of the Medvezhya Formation document a significant $\delta^{13} \mathrm{C}$ excursion. From a moderate trough $(-1.9 \%$ o $3-5 \mathrm{~m}$ above the base of the formation, $\mathrm{C}$-isotopic values rise continuously to the most prominent peak in the entire data set $(+5.4 \% o), 26 \mathrm{~m}$ above the base of the unit. The peak is defined by a single point - a sample just $2 \mathrm{~m}$ higher has a $\delta^{13} \mathrm{C}$ of $+1.9 \%$. With the exception of methanogenesis, which is unlikely in this context, all principal processes known to alter the $\delta^{13} \mathrm{C}$ of carbonates do so by lowering it (Grossman, 1994; Scholle, 1995). Thus, we interpret the Medvezhya peak as genuine but stratigraphically narrow.

Pokrovsky \& Missarzhevsky (1993) provide scattered data on carbonates higher in the succession, suggesting that the drop hinted at in our uppermost sample culminates in a trough of -0.9 to $-0.7 \%$ c c. $8 \mathrm{~m}$ above the C-isotopic peak; this trough is located in the Medvezhya-Kyndyn formation boundary beds. Above this point, they record further positive values +3 to $+4 \%$ o in Kyndyn facies c. $55 \mathrm{~m}$ above the base of the 
Table 1. Elemental and isotopic compositions of late Vendian and Lower Cambrian carbonates, Anabar Massif, northwest Siberia

\begin{tabular}{|c|c|c|c|c|c|c|}
\hline Sample & Depth* & Formation/bed & $\mathrm{Mn} / \mathrm{Sr}$ & $\mathrm{Mg} / \mathrm{Ca}$ & $\delta^{13} \mathrm{C}$ & $\delta^{18} \mathrm{O}$ \\
\hline 139 & 0.5 & Staraya Rechka & 21.70 & 0.545 & -1.5 & -2.4 \\
\hline 140 & 1.0 & " & 29.29 & 0.512 & -1.3 & -4.9 \\
\hline 141 & 2.0 & $"$ & 44.20 & 0.535 & -1.8 & -3.7 \\
\hline 142 & 3.0 & $"$ & 31.11 & 0.537 & -1.1 & -1.1 \\
\hline 143 & 4.0 & $"$ & 14.73 & 0.554 & -2.9 & -3.9 \\
\hline 144 & 5.0 & $"$ & 17.76 & 0.576 & -2.5 & -3.8 \\
\hline 145 & 6.0 & $"$ & 21.97 & 0.535 & -2.4 & -14.8 \\
\hline 146 & 7.0 & $"$ & 19.86 & 0.547 & -2.2 & -17.3 \\
\hline 147 & 8.0 & $"$ & 18.95 & 0.552 & -0.5 & -15.2 \\
\hline 148 & 9.0 & " & 16.74 & 0.522 & -0.5 & -4.0 \\
\hline 149 & 10.0 & $"$ & 25.00 & 0.548 & n.d. & n.d. \\
\hline 150 & 13.0 & $"$ & 14.07 & 0.579 & n.d. & n.d. \\
\hline 151 & 14.0 & $"$ & 23.99 & 0.515 & n.d. & n.d. \\
\hline 152 & 15.0 & $"$ & 16.36 & 0.556 & -2.9 & -11.8 \\
\hline 153 & 16.0 & $"$ & 21.38 & 0.535 & -2.4 & -13.7 \\
\hline 154 & 17.0 & $"$ & 29.52 & 0.519 & -1.5 & -7.9 \\
\hline 155 & 18.0 & $"$ & 24.74 & 0.498 & -0.6 & -4.7 \\
\hline 156 & 19.0 & $"$ & 16.28 & 0.532 & -0.1 & -5.3 \\
\hline 157 & 20.0 & $"$ & 18.52 & 0.529 & -0.3 & -3.5 \\
\hline 158 & 21.0 & $"$ & 22.41 & 0.522 & -0.6 & -3.4 \\
\hline 160 & 23.0 & $"$ & 21.76 & 0.515 & -1.3 & -6.0 \\
\hline 161 & 24.0 & $"$ & 26.60 & 0.508 & -2.0 & -2.9 \\
\hline 164 & n.d. & $"$ & n.d. & n.d. & -2.5 & -15.5 \\
\hline 165 & 19.0 & $"$ & 14.93 & 0.542 & 0.1 & -4.0 \\
\hline 166 & 20.0 & $"$ & 15.20 & 0.517 & 0.2 & -3.8 \\
\hline 167 & 21.0 & $"$ & 15.03 & 0.527 & -2.4 & -3.2 \\
\hline 168 & 22.0 & $"$ & 17.14 & 0.485 & -2.1 & -3.1 \\
\hline 170 & 24.0 & $"$ & 11.42 & 0.547 & -3.9 & -3.9 \\
\hline 171 & 25.0 & $"$ & 12.37 & 0.476 & -4.4 & -15.7 \\
\hline 172 & 26.0 & $"$ & 23.76 & 0.539 & -4.4 & -3.5 \\
\hline 173 & 27.0 & $"$ & 13.64 & 0.557 & -4.1 & -3.5 \\
\hline 174 & 28.0 & $"$ & 16.60 & 0.556 & -2.3 & -4.0 \\
\hline 175 & 29.0 & $"$ & 13.66 & 0.536 & -4.6 & -3.5 \\
\hline 176 & 30.0 & $"$ & 10.05 & 0.493 & -5.1 & -2.7 \\
\hline 177 & 31.0 & $"$ & 11.01 & 0.514 & -5.7 & -3.2 \\
\hline 178 & 32.0 & $"$ & 16.74 & 0.548 & -6.2 & -3.2 \\
\hline 179 & 33.0 & $"$ & 10.32 & 0.520 & -4.3 & -3.1 \\
\hline 180 & 34.0 & $"$ & 8.86 & 0.536 & -4.3 & -2.8 \\
\hline 181 & 35.0 & $"$ & 7.61 & 0.525 & -3.4 & -2.9 \\
\hline 182 & 36.0 & $"$ & 8.06 & 0.512 & -3.4 & -2.3 \\
\hline 184 & 38.0 & $"$ & 13.04 & 0.556 & -4.3 & -3.3 \\
\hline 73 & 38.0 & $"$ & n.d. & n.d. & -2.0 & -7.1 \\
\hline 185 & 39.0 & $"$ & 9.71 & 0.521 & n.d. & n.d. \\
\hline 74 & 39.0 & $"$ & n.d. & n.d. & -1.1 & -5.7 \\
\hline 186 & 40.0 & $"$ & 8.55 & 0.537 & -2.3 & -3.4 \\
\hline 75 & 40.0 & $"$ & 9.66 & 0.632 & -3.5 & -3.3 \\
\hline 76 & 41.0 & $"$ & 16.32 & 0.634 & -4.5 & -4.9 \\
\hline 187 & 41.0 & Staraya Rechka & 11.30 & 0.556 & -3.7 & -3.5 \\
\hline 78 & 43.0 & " & 16.97 & 0.631 & -4.2 & -2.4 \\
\hline 190 & 44.0 & $"$ & 9.18 & 0.532 & -3.1 & -3.1 \\
\hline 79 & 44.0 & $"$ & 11.24 & 0.619 & n.d. & n.d. \\
\hline 191 & 45.0 & $"$ & 7.20 & 0.552 & -2.9 & -2.8 \\
\hline 80 & 45.0 & $"$ & 9.33 & 0.643 & -2.2 & -3.8 \\
\hline $192 \mathrm{~A}$ & 46.0 & $"$ & n.d. & n.d. & -3.7 & -0.8 \\
\hline $192 B$ & 46.0 & $"$ & n.d. & n.d. & -3.3 & -2.8 \\
\hline 81 & 46.0 & $"$ & 4.83 & 0.652 & n.d. & n.d. \\
\hline 193 & 47.0 & $"$ & 7.60 & 0.512 & -2.9 & -2.7 \\
\hline 82 & 47.0 & $"$ & 11.50 & 0.652 & -2.8 & -5.1 \\
\hline 194 & 48.0 & $"$ & 8.78 & 0.527 & -2.7 & -3.0 \\
\hline 83 & 48.0 & $"$ & 13.85 & 0.622 & -3.7 & -16.4 \\
\hline 195 & 49.0 & $"$ & 11.36 & 0.495 & -2.6 & -2.0 \\
\hline 85 & 50.0 & $"$ & 31.60 & 0.578 & -1.9 & -9.4 \\
\hline 87 & 53.5 & Manykai/II & 3.37 & 0.425 & -4.4 & -11.0 \\
\hline 88 & 55.0 & $"$ & 2.59 & 0.404 & -3.6 & -7.5 \\
\hline $89 \mathrm{~A}$ & 68.5 & Manykai/III & 7.38 & 0.613 & -2.0 & -8.8 \\
\hline $89 \mathrm{~B}$ & 68.5 & " & 6.87 & 0.571 & -1.5 & -6.2 \\
\hline 222 & 70.0 & $"$ & 2.70 & 0.089 & 1.8 & -6.1 \\
\hline 91 & 71.0 & $"$ & 1.66 & 0.065 & 1.8 & -5.3 \\
\hline 93 & 73.0 & $"$ & 0.15 & 0.016 & 0.2 & -5.4 \\
\hline 94 & 74.0 & $"$ & 0.87 & 0.012 & -1.9 & -9.0 \\
\hline 210 & 74.0 & $"$ & 0.08 & 0.015 & 0.2 & -5.6 \\
\hline 95 & 75.0 & $"$ & 1.10 & 0.016 & -2.1 & -6.2 \\
\hline
\end{tabular}




\begin{tabular}{|c|c|c|c|c|c|c|}
\hline Sample & Depth* & Formation/bed & $\mathrm{Mn} / \mathrm{Sr}$ & $\mathrm{Mg} / \mathrm{Ca}$ & $(\%$, PDB $)$ & $\delta^{18} \mathrm{O}$ \\
\hline 213 & 76.0 & $"$ & 1.53 & 0.015 & -3.5 & -6.9 \\
\hline 96 & 77.0 & $"$ & 1.60 & 0.019 & -3.8 & -6.8 \\
\hline 97 & 78.0 & $"$ & 0.94 & 0.011 & -3.5 & -6.4 \\
\hline 214 & 79.0 & $"$ & 1.22 & 0.023 & -4.2 & -6.2 \\
\hline 215 & 80.0 & $"$ & 0.77 & 0.018 & n.d. & n.d. \\
\hline 216 & 81.0 & $"$ & 2.13 & 0.278 & -2.5 & -5.5 \\
\hline 98 & 81.5 & Manykai/IV & 1.56 & 0.293 & -1.5 & -6.9 \\
\hline 100 & 85.5 & $"$ & 1.44 & 0.236 & -1.6 & -7.1 \\
\hline 101 & 86.5 & $"$ & 1.27 & 0.226 & -1.4 & -6.6 \\
\hline 102 & 87.5 & $"$ & 1.01 & 0.148 & -0.8 & -6.4 \\
\hline 103 & 88.5 & $"$ & 1.87 & 0.387 & -1.7 & -6.7 \\
\hline 104 & 89.5 & $"$ & 1.65 & 0.347 & -1.7 & -5.7 \\
\hline 105 & 90.5 & $"$ & 2.07 & 0.187 & -2.9 & -6.9 \\
\hline 217 & 92.0 & $"$ & 1.62 & 0.482 & -3.7 & -5.2 \\
\hline 218 & 93.0 & $"$ & 2.19 & 0.481 & -3.5 & -4.7 \\
\hline 219 & 94.0 & $"$ & 1.52 & 0.444 & -2.8 & -5.2 \\
\hline 220 & 95.0 & Manykai/V & 3.13 & 0.445 & -2.5 & -4.8 \\
\hline 221 & 96.0 & " & 0.60 & 0.018 & -1.1 & -5.5 \\
\hline 107 & 99.0 & $"$ & 1.28 & 0.129 & -1.1 & -5.8 \\
\hline $108 \mathrm{~A}$ & 100.0 & $"$ & 1.74 & 0.338 & -1.3 & -6.6 \\
\hline $108 \mathrm{~B}$ & 100.0 & $"$ & 1.80 & 0.355 & -1.3 & -6.7 \\
\hline 109 & 101.0 & $"$ & 0.96 & 0.123 & -0.6 & -6.0 \\
\hline 110 & 102.0 & Manykai/V & 0.94 & 0.214 & -0.3 & -6.6 \\
\hline 111 & 103.5 & Manykai/VI & 2.22 & 0.466 & -1.6 & -5.8 \\
\hline 112 & 105.0 & " & 0.55 & 0.069 & 0.7 & -6.2 \\
\hline 113 & 106.0 & $"$ & 0.77 & 0.069 & 0.7 & -6.3 \\
\hline 114 & 107.0 & $"$ & 2.67 & 0.528 & -0.1 & -5.9 \\
\hline 115 & 108.0 & $"$ & 5.39 & 0.623 & 0.2 & -7.9 \\
\hline 116 & 109.0 & Manykai/VII & 5.29 & 0.543 & 0.0 & -6.5 \\
\hline 117 & 110.0 & " & 8.65 & 0.566 & 1.8 & -5.0 \\
\hline 118 & 111.5 & $"$ & 5.17 & 0.558 & n.d. & n.d. \\
\hline 119 & 112.0 & $"$ & 2.14 & 0.427 & 1.2 & -5.7 \\
\hline 120 & 115.0 & $"$ & 1.42 & 0.525 & 2.5 & -4.7 \\
\hline 121 & 116.0 & Manykai/VIII & 0.35 & 0.047 & 1.5 & -8.2 \\
\hline 122 & 117.0 & " & 0.46 & 0.004 & 1.6 & -7.9 \\
\hline 123 & 118.0 & $"$ & 0.60 & 0.009 & 1.3 & -8.4 \\
\hline 124 & 119.0 & $"$ & 0.42 & 0.014 & 1.2 & -8.4 \\
\hline 125 & 120.0 & $"$ & 0.68 & 0.034 & 1.7 & -8.3 \\
\hline 126 & 121.0 & $"$ & 0.61 & 0.007 & 1.6 & -8.0 \\
\hline 127 & 122.0 & $"$ & 0.38 & 0.015 & -0.8 & -11.0 \\
\hline $128 \mathrm{~A}$ & 123.0 & $"$ & 0.10 & 0.017 & 0.8 & -6.2 \\
\hline $128 \mathrm{~B}$ & 123.0 & $"$ & 0.27 & 0.020 & 0.7 & -6.6 \\
\hline 129 & 125.0 & $"$ & 3.28 & 0.419 & -1.3 & -6.5 \\
\hline 130 & 127.0 & $"$ & 3.04 & 0.393 & -0.6 & -5.5 \\
\hline 131 & 128.0 & " & 2.82 & 0.400 & -0.5 & -5.5 \\
\hline 132 & 129.0 & Manykai/IX & 0.67 & 0.029 & 1.5 & -5.5 \\
\hline 133 & 130.0 & $"$ & 0.65 & 0.028 & 1.6 & -5.4 \\
\hline 134 & 131.0 & $"$ & 0.87 & 0.008 & 0.9 & -8.5 \\
\hline 135 & 132.0 & $"$ & 0.56 & 0.041 & 1.2 & -5.2 \\
\hline 136 & 133.0 & $"$ & 0.50 & 0.007 & 0.9 & -8.4 \\
\hline 137 & 134.0 & $"$ & 0.49 & 0.008 & 0.4 & -9.8 \\
\hline 138 & 135.0 & $"$ & 0.34 & 0.009 & 0.6 & -10.1 \\
\hline 199 & 136.0 & Medvezhya & 2.59 & 0.016 & -1.0 & -6.2 \\
\hline 200 & 137.0 & $"$ & 1.94 & 0.134 & -1.0 & -6.9 \\
\hline 224 & 138.0 & $"$ & 2.29 & 0.059 & -1.2 & -6.2 \\
\hline 225 & 139.0 & $"$ & 1.73 & 0.015 & -1.9 & -6.0 \\
\hline 226 & 141.0 & $"$ & 1.95 & 0.030 & -1.9 & -6.0 \\
\hline 227 & 143.0 & $"$ & 1.44 & 0.040 & -0.3 & -5.6 \\
\hline 201 & 144.0 & $"$ & 3.44 & 0.026 & -0.4 & -5.9 \\
\hline 202 & 146.0 & $"$ & 1.11 & 0.019 & -0.8 & -5.8 \\
\hline 203 & 148.0 & $"$ & 0.89 & 0.009 & -0.4 & -5.8 \\
\hline 204 & 150.0 & $"$ & 0.64 & 0.014 & -0.6 & -5.2 \\
\hline 205 & 152.0 & $"$ & 0.53 & 0.015 & 1.2 & -5.3 \\
\hline 206 & 154.0 & $"$ & 0.91 & 0.011 & 1.6 & -5.0 \\
\hline 207 & 159.0 & $"$ & 3.60 & 0.035 & 3.6 & -4.9 \\
\hline 208 & 161.0 & $"$ & 0.19 & 0.015 & 5.4 & -3.7 \\
\hline 209 & 163.0 & $"$ & 0.64 & 0.010 & 1.9 & -6.0 \\
\hline
\end{tabular}

* Height in metres above the base of the Staraya Rechka Formation. 

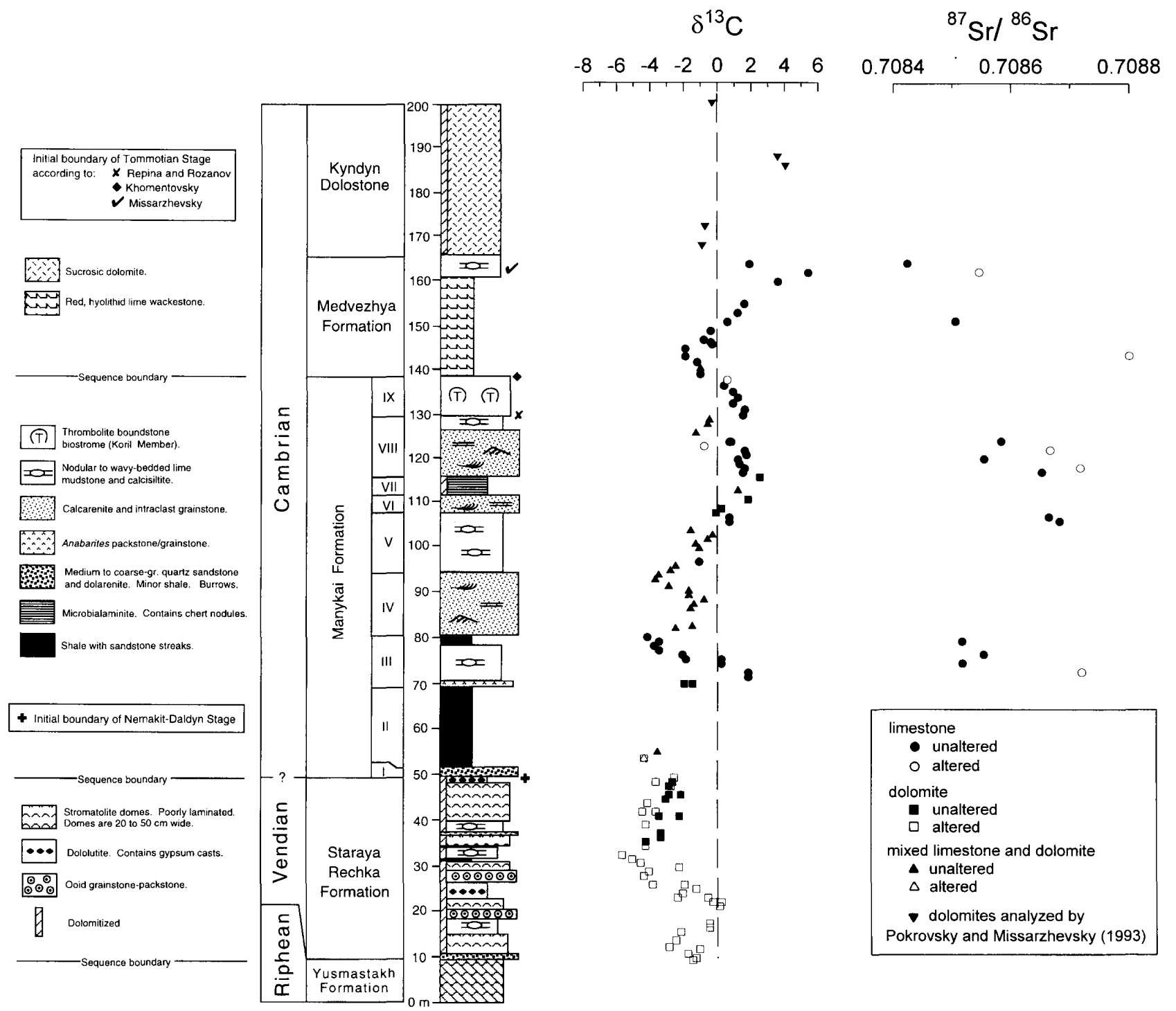

Figure 7. C- and Sr-isotopic determinations for the terminal Proterozoic/Lower Cambrian succession exposed along the Kotuikan River. See also Table 1.

Medvezhya Formation. Their uppermost sample, another c. $14 \mathrm{~m}$ above the upper peak, suggests a further interval of values near $0 \%$.

In general, the $\mathrm{C}$-isotopic curve in Figure 7 confirms the findings of Pokrovsky \& Missarzhevsky (1993), but our higher sampling density provides more detail in the pattern of secular variation and more pronounced isotopic maxima and minima, whose peaks and troughs occupy only thin intervals of the section. The difference is particularly important in the Medvezhya Formation, for which Pokrovsky \& Missarzhevsky (1993) obtained only nine $\mathrm{C}$-isotopic values. Perhaps for this reason, their curve does not show the full amplitude of the most prominent isotopic excursion in the entire section - the sharp, strongly positive peak at the $26 \mathrm{~m}$ level.

\section{4.d. Strontium-isotopic results}

Results of Sr-isotopic analyses of a selected suite of microsamples from pure limestones with low $\mathrm{Mn} / \mathrm{Sr}$ are presented in Table 2 and shown graphically in Figure 7. Isotope dilution analyses indicate relatively low concentrations of $\mathrm{Sr}(<200 \mathrm{ppm})$ and/or high $87 \mathrm{Rb} /{ }^{86} \mathrm{Sr}$ $(>0.005)$ in some samples. Our empirical studies (Derry et al. 1989; Derry, Kaufman \& Jacobsen, 1992; Kaufman, Knoll \& Awramik, 1992; Kaufman, Jacobsen \& Knoll, 1993; Narbonne, Kaufman \& Knoll, 1994) suggest that samples which have lost $\mathrm{Sr}$ due to meteoric diagenesis or have authigenic clays containing $\mathrm{Rb}$ will likely have altered Sr-isotopic compositions (see also Veizer, 1983). Therefore, we consider that samples shown as open circles and triangles in Figures 7 and 8 do not retain primary ${ }^{87} \mathrm{Sr} /{ }^{86} \mathrm{Sr}$ signatures.

Least-altered samples show a distinct pattern of stratigraphic variation in ${ }^{87} \mathrm{Sr} /{ }^{86} \mathrm{Sr}$ through the sampled interval. This trend is anchored in Bed III at a value of slightly greater than 0.7085 by three closely-spaced samples. About $30 \mathrm{~m}$ above this level (in Bed V), the curve peaks at values around 0.7087 - again corroborated by closelyspaced samples. Strontium-isotopic compositions drop 
Table 2. Sr isotope analyses of Manykai and Medvezhya limestones

\begin{tabular}{lcccc}
\hline Sample & Depth* & $\begin{array}{c}\mathrm{Sr} \\
(\mathrm{ppm})\end{array}$ & ${ }^{87} \mathrm{Rb} /{ }^{86} \mathrm{Sr}$ & ${ }^{87} \mathrm{Sr}{ }^{86} \mathrm{Sr}$ \\
\hline 91 & 71.0 & 151 & 0.009223 & 0.708719 \\
93 & 73.0 & 587 & 0.001541 & 0.708517 \\
95 & 75.0 & 632 & 0.000962 & 0.708553 \\
97 & 78.0 & 398 & 0.002497 & 0.708516 \\
215 & 80.0 & 247 & 0.015055 & n.d. \\
102 & 87.5 & 211 & 0.011894 & 0.708992 \\
105 & 90.5 & 95 & 0.012539 & n.d. \\
221 & 96.0 & 362 & 0.007127 & n.d. \\
109 & 101.0 & 183 & 0.015552 & n.d. \\
112 & 105.0 & 714 & 0.005020 & 0.708682 \\
113 & 106.0 & 157 & 0.007361 & 0.708664 \\
121 & 116.0 & 379 & 0.002004 & 0.708652 \\
122 & 117.0 & 115 & 0.008453 & 0.708717 \\
124 & 119.0 & 352 & 0.001425 & 0.708554 \\
126 & 121.0 & 380 & 0.000117 & 0.708666 \\
$128 \mathrm{~A}$ & 123.0 & 1128 & 0.000012 & 0.708583 \\
132 & 129.0 & 203 & 0.011126 & n.d. \\
135 & 132.0 & 324 & 0.177953 & n.d. \\
225 & 139.0 & 396 & 0.009838 & 0.708843 \\
202 & 146.0 & 116 & 0.012568 & 0.709049 \\
204 & 150.0 & 507 & 0.005993 & 0.708506 \\
208 & 161.0 & 378 & 0.007598 & 0.708546 \\
209 & 163.0 & 461 & 0.003471 & 0.708424 \\
\hline & & & & \\
\hline
\end{tabular}

* height in metres above the base of the Staraya Rechka Formation.

steadily through the next $57 \mathrm{~m}$ of section to 0.7084 at the top of the Medvezhya limestones.

\section{Chemo- and biostratigraphic correlation with southeastern Siberia}

The best available C-isotopic record for uppermost Proterozoic and basal Cambrian carbonates comes from the sections along the Aldan and Lena rivers that contain the definitional initial Tommotian boundary, type Tommotian succession and associated fossil assemblages discussed in Section 3 (Magaritz, Holser \& Kirschvink, 1986; Magaritz et al. 1991; Kirschvink et al. 1991; Brasier, Khomentovsky \& Corfield, 1993; Brasier et al. 1994b; Fig. 9). In principle, chemostratigraphic correlation between these sections and the Kotuikan River involves the matching of successive isotopic peaks and troughs. In practice, however, the comparison is straightforward only if the two profiles (1) record basin-wide biogeochemical events, (2) reflect a comparable partitioning of time between sediments and hiatuses, and (3) are equally well sampled and screened for diagenetic alteration. Of these criteria, only the first may be met in this case.

Petrological and geochemical tests indicate that diagenesis did not play an important role in generating the isotopic profile recorded in the western Anabar, and the similarities of the western Anabar and southeastern Siberian curves both to each other and to other sections as distant as Morocco and India suggest that the main determinants of isotopic pattern are global biogeochemical events. The nature of these events remains enigmatic. Stratigraphic variations in the $\delta^{13} \mathrm{C}$ of carbonates and cooccurring organic matter record secular change in the

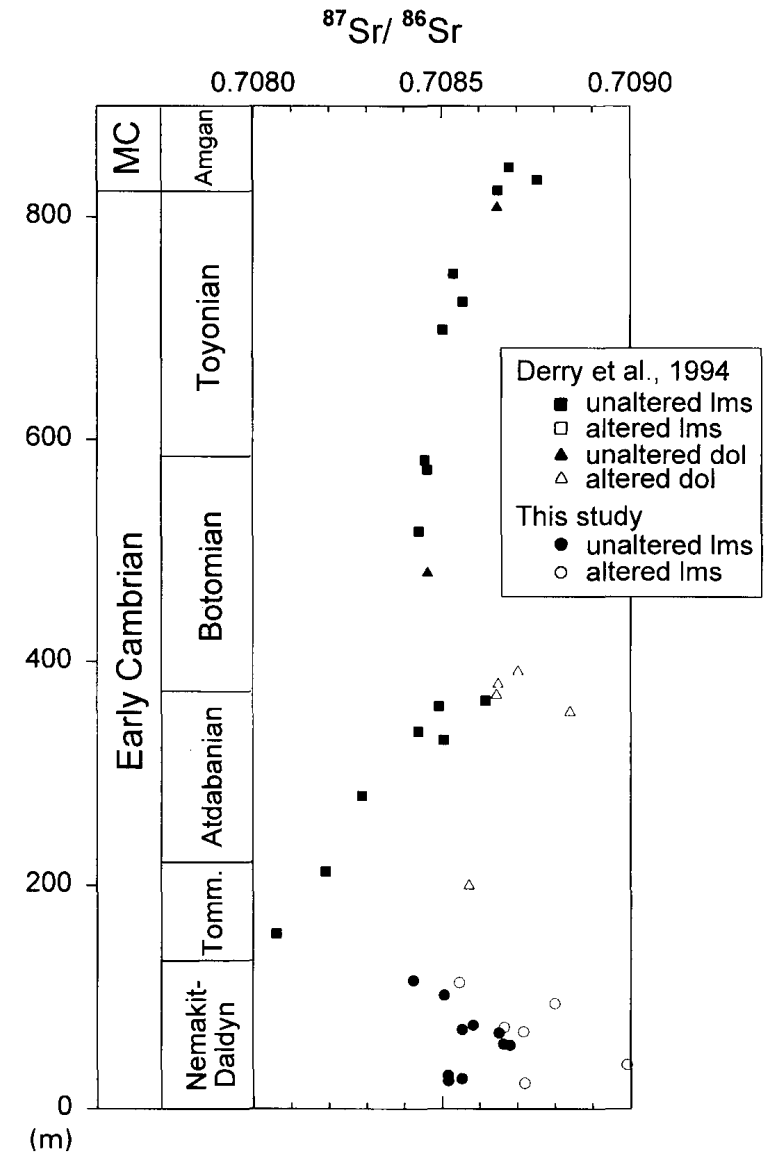

Figure 8. Composite Sr-isotopic profile for Early Cambrian time, based on data reported in Derry et al. (1994) and this paper.

instantaneous burial ratio of the two carbon phases, with increases in $\delta^{13} \mathrm{C}$ values reflecting higher proportional burial rates of organic carbon (Hayes, 1993). Such variations arise because of secular changes in oceanic circulation patterns, but whether increased proportional fluxes of organic $\mathrm{C}$ into sediments reflect increased primary production or enhanced burial at more or less constant production rates is impossible to ascertain from isotopic data alone (Kump, 1991). Large, rapid negative excursions that follow intervals of ${ }^{13} \mathrm{C}$ enrichment in the surface ocean may additionally or alternatively indicate the return to the surface of isotopically light dissolved inorganic carbon generated at depth. Excursions from markedly positive to negative $\delta^{13} \mathrm{C}$ values occur in association with both Sturtian and Varangerian glaciogenic rocks (Kaufman \& Knoll, 1995), and also accompany Late Ordovician glaciation (Marshall \& Middleton, 1990; Long, 1993; Wang et al. 1993). The large negative excursion recorded in Medvezhya carbonates (and in other contemporaneous successions, see Sections 6 and 7.c) is consistent with reports of 'Late Sinian' glaciogenic rocks (Chumakov, 1985; Hambrey \& Harland, 1985; BertrandSarfati et al. 1995); however, age constraints on these tillites require tightening before any association of earliest Cambrian isotopic events and climatic change can be tested. 


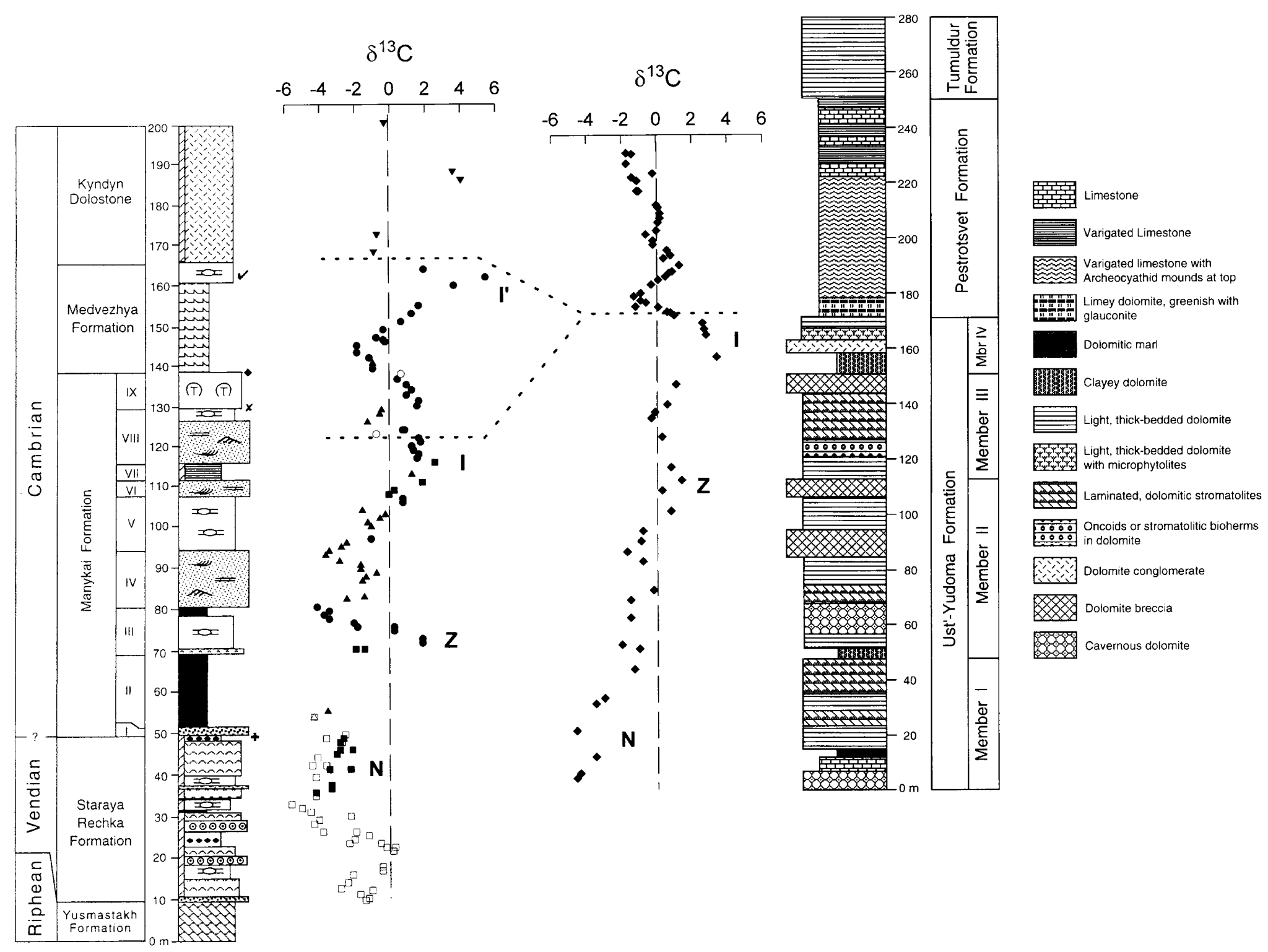

Figure 9. Chemostratigraphic correlation of the Kotuikan River and Dvortsy sections, showing the stratigraphic interval within the Anabar section interpreted as corresponding to the sub-Tommotian unconformity in southeastern Siberia. 


\section{5.a. Staraya Rechka and lower Manykai correlation}

The strong negative $\mathrm{C}$-isotopic excursion seen near the base of the upper Staraya Rechka Formation (labelled 'N' in Fig. 4) provides a distinctive isotopic datum that can be correlated with a comparably $(-4.5 \%)$ negative interval at the base of the measured part of the Ust'-Yudoma Formation at Dvortsy, southeastern Siberia (Magaritz, Holser \& Kirschvink, 1986; Fig. 9; note that the base of the Ust'-Yudoma Formation is not exposed at Dvortsy and the underlying Aim Formation of the Yudoma Group is missing throughout the Aldan region (Semikhatov \& Serebryakov, 1983))

The isotopic peak in Manykai Bed III (just above the base of parasequence 2) is here correlated with the peak midway through the Ust'-Yudoma section at Dvortsy labelled 'Z' by Brasier, Khomentovsky \& Corfield (1993; Magaritz, Holser \& Kirschvink, 1986; Kirschvink et al. 1991; Fig. 9). Three arguments favour this correlation: (1) the peaks occupy a similar position relative to both the correlated lower Staraya Rechka/basal Ust'-Yudoma troughs and large positive excursions higher in the sections, (2) they are of similar magnitude, and (3) they are both associated stratigraphically with fossils of the Anabarites trisulcatus Zone. As noted by Brasier, Khomentovsky \& Corfield (1993), A. trisulcatus and associated taxa appear to enter the record at slightly different times in different Siberian sections; the multispecies assemblage in Manykai Bed III appears at nearly the same level as its counterpart along the Nemnekey River in southeastern Siberia - well above the first appearance of a monospecific A. trisuclatus faunule at the base of the Manykai Formation and still farther above the first appearance of Cambrotubulus sp. in the Olenek region (Khomentovsky \& Karlova, 1993; Knoll et al. 1995a). Correlation of the Manykai Bed III peak with Ust'-Yudoma peak $\mathrm{Z}$ also suggests that the lower boundary of the Purella antiqua Zone - just above peak $\mathrm{Z}$ in Uchuro-Maya sections (Brasier, Khomentovsky \& Corfield, 1993) - is located well below the actual first appearance of $P$. antiqua Zone faunas in the Manykai Formation (see also Brasier et al. 1994b, who drew a similar conclusion from the data of Pokrovsky \& Missarzhevsky, 1993).

A second C-isotopic peak occurs near the top of Manykai Bed VII, just beneath the boundary of parasequences 3 and 4 (Fig. 7). The $+3.3 \%$ value of this peak matches precisely that found just beneath the subTommotian unconformity at Dvortsy (Magaritz, Holser \& Kirschvink, 1986; Peak 'I' of Brasier, Khomentovsky \& Corfield, 1993; Fig. 9). Besides their magnitudes and relative stratigraphic positions, these prominent peaks are tethered by their occurrence in stratigraphic proximity to relatively diverse faunas of the $P$. antiqua Zone. Particularly in sections along the Dzhanda River c. 100 $\mathrm{km}$ east of the Aldan exposures, uppermost Ust'-Yudoma carbonates contain well-preserved faunas whose taxonomic composition compares closely with assemblages found in Bed IX of the Manykai Formation (Khomentovsky \& Karlova, 1993). If this correlation is correct, diverse $P$. antiqua Zone assemblages in the Manykai Formation appear after their counterparts in southeastern Siberia.

\section{5.b. Upper Manykai and Medvezha correlation}

At Dvortsy and elsewhere in southeastern Siberia, Peak I is succeeded by an excursion to moderately negative $\mathrm{C}$ isotopic values just above the base of the fossiliferous Pestrotsvet Formation. Above this negative excursion, a peak of magnitude $>+2 \%$ occurs in the Aldan-Lena sections only in the mid-Atdabanian P. anabarus Zone (Peak $\mathrm{V}$ of Brasier et al. 1994a). In contrast, in the western Anabar section, the negative isotopic excursion immediately above the correlative of Peak I occurs within Manykai Bed VIII, below the lowermost point at which any stratigrapher has placed the basal Tommotian boundary. The succeeding $+5.4 \%$ peak in the upper Medvezhya Formation has a magnitude unmatched anywhere in the Dvortsy profile; it occurs in stratigraphic association with uppermost Nemakit-Daldynian or Tommotian fossils well below the accepted regional base of the Atdabanian Stage.

The simplest explanation for this is that the interval extending from Bed VIII of the Manykai Formation through at least the lower $26 \mathrm{~m}$ of the Medvezhya Formation preserves a sedimentary and palaeontological record of the time interval represented in southeastern Siberia by the sub-Tommotian unconformity (Fig. 9). As discussed here, this correlation is consistent with biostratigraphic data and potentially resolves outstanding uncertainties in the interregional correlation of earliest Cambrian strata in Siberia.

$\mathrm{Sr}$-isotopic data provide independent support for placement of the basal Tommotian boundary above the $26 \mathrm{~m}$ mark of the Medvezhya Formation. The (relatively) low ${ }^{87} \mathrm{Sr} /{ }^{86} \mathrm{Sr}$ values documented in the type lower Tommotian carbonates by Derry et al. (1994) is not seen in the Kotuikan section (Figs 7, 8). Indeed, accepting the stratigraphic interpretation proposed on the basis of C-isotopes, the decrease in ${ }^{87} \mathrm{Sr} /{ }^{86} \mathrm{Sr}$ documented from Manykai Bed V through the top of the Medvezhya limestones projects smoothly into the relatively low values $(c$. 0.7081) reported by Derry et al. (1994) for basal Tommotian limestones in southeastern Siberia (Fig. 8).

Strontium isotope secular variations can also be projected back into the Vendian. Below the Vendian/Cambrian boundary, in unaltered limestones slightly older than those in the Staraya Rechka Formation (the Spitzkopf Formation in Namibia), ${ }^{87} \mathrm{Sr} /{ }^{86} \mathrm{Sr}$ values match those of the lowermost Nemakit-Daldynian samples analysed here (cf. Kaufman, Jacobsen \& Knoll, 1993). The overall rise in ${ }^{87} \mathrm{Sr} /{ }^{86} \mathrm{Sr}$ inferred for palaeoseawater from basal Vendian to middle Nemakit-Daldynian times $(0.7066$ to 0.7086$)$ has been attributed to enhanced continental erosion associated with a latter phase of the 
Pan-African orogeny (Kaufman, Jacobsen \& Knoll, 1993; Gorokhov et al. 1994). Derry et al. (1994) suggested a similar scenario for the subsequent rise in ${ }^{87} \mathrm{Sr} /{ }^{86} \mathrm{Sr}(0.7081$ to 0.7088$)$ from the base of the Tommotian to early Middle Cambrian times. A corollary to these interpretations is that the drop in palaeoseawater Sr-isotopic values from the Nemakit-Daldynian peak to the basal Tommotian valley represents either a transient decline in continental inputs or a significant hydrothermal event.

Above the $28 \mathrm{~m}$ level of the Medvezhya Formation, isotopic data are sparse, but they are consistent with both biostratigraphic data and the preceding interpretations. Mildly negative $\delta^{13} \mathrm{C}$ values $c .34 \mathrm{~m}$ above the base of the Medvezhya Formation (Pokrovsky \& Missarzhevsky, 1993) are consistent with Tommotian deposition, and according to Repina \& Rozanov (1992), Burithes distortus, a putative index fossil for the $D$. regularis Zone, first appears 25-30 $\mathrm{m}$ above the base of the formation. Khomentovsky \& Karlova (1992) place its first appearance above the $30 \mathrm{~m}$ mark. The uppermost peak recorded by Pokrovsky \& Missarzhevsky (1993) in the Kyndyn Formation is also consistent with biostratigraphic evidence for Adtabanian deposition (Repina \& Rozanov, 1992). If these interpretations are correct, the uppermost Medvezhya/lower Kyndyn succession must be condensed relative to southeastern Siberia or marked by cryptic unconformities. Northern Siberia was tectonically active during latest Proterozoic and Early Cambrian times, providing a mechanism for differential uplift and subsidence across the platform (Pelechaty, Kaufman \& Grotzinger, 1996).

\section{5.c. Alternative possibilities for correlation}

The correlation favoured here is not the only one that could be proposed on the basis of existing data, and it is important to consider alternatives. Perhaps the most obvious alternative is that the pronounced peak $26 \mathrm{~m}$ above the base of the Medvezhya Formation correlates directly with Dvortsy peak I (Pokrovsky \& Missarzhevsky, 1993). In this alternative, the difference in amplitude between the two peaks must be explained by one of two arguments. The true magnitude of the Dvortsy peak may be underestimated as a result of low sampling density in the critical interval or diagenetic depletion of ${ }^{13} \mathrm{C}$ in the carbonates. Alternatively, one might propose that strong basinal heterogeneity in $\mathrm{C}$-isotopic composition developed within the Early Cambrian seaway covering the Siberian Platform.

In this interpretation, Tommotian strata still begin more than $26 \mathrm{~m}$ above the base of the Medvezhya Formation, but Anabar strata record both fossils and isotopic events not reported from correlative beds in southeastern Siberia (Pokrovsky \& Missarzhevsky, 1993).

Several arguments militate against this alternative:

(1) A number of prominent $\mathrm{C}$-isotopic excursions are recorded in both older Neoproterozoic and younger
Phanerozoic (e.g. Late Cambrian, Late Ordovician, Late Permian, Cenomanian) carbonates, and strong peaks $(>+5 \%$ ) in one region seldom, if ever, match up with relatively minor excursions elsewhere (see, e.g. Smith et al. 1994; Erwin, 1993; Pratt, Force \& Pomerol, 1991); indeed, in Neoproterozoic basins where strong positive isotopic excursions have been identified in multiple sections, amplitude is consistent among correlative peaks (see, e.g. Knoll et al. 1986; Narbonne, Kaufman \& Knoll, 1994; Pelechaty, Kaufman \& Grotzinger, 1996). Without detailed diagenetic studies of the Dvortsy carbonates, we cannot speculate whether some process may have decreased $\delta^{13} \mathrm{C}$ values in these samples.

(2) The principal biostratigraphic corollary of this alternative - that the basal Cambrian fossil distribution in southeastern Siberia faithfully records evolutionary first appearances, whereas the sequential first appearances of taxa in the north reflects episodic migration - is contrary to palaeontological experience in younger rocks.

(3) Among the admittedly small number of NemakitDaldynian/Tommotian sections for which C-isotopic data are available, the Dvortsy section is actually unusual in not including $\delta^{13} \mathrm{C}$ values $>+5 \%$ (see Section 7.c).

We cannot rule out the possibility that sampling density at Dvortsy was too low to capture the short-lived maximum of this excursion, but this can, of course, be tested.

Another potential alternative is that the Anabar succession above Manykai Bed VII correlates with the Tommotian to Atdabanian succession in southeastern Siberia, compatible with the biostratigraphic interpretation of Repina \& Rozanov (1992). In this case, the small peak in Manykai Bed IX would match up with a minor peak within the $D$. regularis Zone in the southeast, leaving the strong upper Medvezhya peak to correlate with a succeeding Atdabanian excursion. Problems with this alternative include the following:

(1) It does not solve the problem of matching a strong $(>+5 \%$ ) peak in one section with a minor $(<+2 \%$ if correlation is made to lower Atdabanian Peak IV of Brasier et al. $1994 b$, and $c .+3 \%$ if one chooses the more prominent Peak V in the $P$. anabarus Zone) excursion in another.

(2) It requires that the lower boundary of the Adtabanian Stage be placed at or below the 27 m mark of the Medvezhya Formation, even though all biostratigraphic interpretations place this level within the Tommotian.

(3) Sr-isotopic data for the upper Manykai and lower Medvezhya formations are not consistent with a Tommotian age for these rocks.

It is possible to articulate a third class of interpretation, in which Kotuikan intervals corresponding to hiatuses in southeastern Siberia are smaller than those suggested in our preferred alternative; however, no alternative in this class escapes the problems noted earlier in this section. The principal correlation proposed in this paper does not suffer from the problems that accompany all other rea- 
sonable alternatives, and so we prefer it. Regardless of preference, it can be tested because it makes predictions about (1) the results of denser sampling and more detailed evaluation of diagenesis in southeastern Siberian sections and (2) the stratigraphic relationship between isotopic profiles and SSFs in other sections within and beyond the Siberian Platform.

\section{Chemo- and biostratigraphic correlation with the Olenek region of northern Siberia}

The Staraya Rechka succession can be compared with the latest Proterozoic (Yudomian) succession that underlies Nemakit-Daldynian rocks in the Olenek Uplift, $600 \mathrm{~km}$ to the east of the Kotuikan River. Previously, it was broadly accepted (e.g. Semikhatov, Komar \& Serebryakov, 1970; Khomentovsky, 1976, 1990; Shpunt, Shapovalova \& Shamshina, 1982; Semikhatov \& Serebryakov, 1983; Khomentovsky \& Karlova, 1994) that the Staraya Rechka Formation correlates with the entire Yudomian succession in the Olenek region (Maastakh, Khatyspyt and Turkut formations) or to its post-Maastakh part. However, C-isotopic data (Knoll et al. 1995a) preclude such interpretation. In the Olenek section, a negative excursion comparable in magnitude to that recorded in the Staraya Rechka Formation is confined to the thin, upper sedimentary sequence of the Turkut Formation. The mildly negative ( 0 to $-2.5 \%$ o) $\delta^{13} \mathrm{C}$ values seen in the lower Staraya Rechka suggest correlation with some or all of the lower Turkut Formation, but do not support the hypothesis that the underlying Khatyspyt and Maastakh formations have time equivalents in the western Anabar region. This corroborates and refines earlier conclusions that terminal Proterozoic (Yudomian) transgressions flooded different parts of the Siberian Platform at different times (e.g. Semikhatov, Komar \& Serebryakov, 1970; Khomentovsky, 1976).

The earliest SSFs of Cambrian aspect recorded in the Olenek region are Cambrotubulus sp. found $30 \mathrm{~m}$ below the top of the Turkut Formation (Karlova, 1987; Khomentovsky \& Karlova, 1993). Carbon-isotopic data demonstrate that this occurrence lies well below the base of the Nemakit-Daldynian Stage in the western Anabar section, at a level equal to or below the lower Staraya Rechka Formation. Anabarites sp. occurs in uppermost Turkut carbonates that correlate chemostratigraphically with upper Staraya Rechka or lowermost Manykai strata (Khomentovsky \& Karlova, 1993). Shales and carbonates of the overlying Kessyusa Formation contain a succession of skeletal fossils similar to that found in the western Anabar region (Khomentovsky \& Karlova, 1993). In the drainage of the Khorbusuonka River, lower Kessyusa rocks assigned to the A. trisulcatus Zone do not include carbonates, but middle Kessyusa strata contain both a faunal assemblage referable to the $P$. antiqua Zone and a C-isotopic peak that can be correlated with Peak I in Manykai Bed VII and the uppermost Ust'-Yudoma Formation (Knoll et al. 1995a).
A sequence boundary separates middle and upper Kessyusa strata (Khomentovsky \& Karlova, 1992; Knoll et al. 1995a). Upper Kessyusa rocks have been assigned to the Tommotian $N$. sunnaginicus Zone (Khomentovsky \& Karlova, 1993), but all taxa they share with the western Anabar region have first appearances below the NemakitDaldynian/Tommotian boundary. This and a second $\mathrm{C}$-isotopic peak whose magnitude exceeds anything recorded in southeastern Siberia, suggest that the Nemakit-Daldynian/Tommotian boundary may lie at the Kessyusa/Erkeket boundary. An unconformity at this boundary is documented by erosional relief of up to one metre (Grotzinger \& Knoll, pers. observation); argillaceous, maroon limestones of the Erkeket Formation record onlap over the previously exposed craton. (As noted in Section 6, the observation that many taxa in the upper Kessyusa Formation occur in rocks of the N. sunnaginicus Zone in southeastern Siberia (Khomentovsky $\&$ Karlova, 1992) does not provide persuasive evidence for an opposing interpretation.)

\section{Discussion}

\section{7.a. Biostratigraphy}

Previous correlations between northwestern and southeastern Siberia start from the premise that rocks correlate with rocks, rather than with omission surfaces. Our data suggest that this assumption may not be valid. None the less, our preferred placement of the NemakitDaldynian/Tommotian boundary in the western Anabar section approximates that of Missarzhevsky (1989) and Khomentovsky \& Karlova (1993).

As most or all of the small shelly fossils previously suggested to mark the $N$. sunnaginicus Zone appear to have evolved prior to the beginning of the Tommotian, their use in the unequivocal recognition of this zone or even stage is problematic - this is the argument of Landing (1994, and earlier papers). To date there is no record of archaeocyathids in the sub-Tommotian of the western Anabar; thus, these fossils may provide more robust markers for early Tommotian time. Whether or not a distinct $N$. sunnaginicus Zone can be recognized in Siberia or elsewhere in the absence of archaeocyathans is questionable (Qian \& Bengtson, 1989; Landing, 1992, 1994); however, the richness of stratigraphic information recorded by the sequential appearance of SSF taxa in the western Anabar holds the promise that additional zones can be recognized in the upper Nemakit-Daldynian Stage, as suggested by Missarzhevsky (1989). On the other hand, Khomentovsky \& Karlova's (1994) comment that even minor environmental fluctuations seem to have affected the local stratigraphic distribution of early shelly fossils is apt.

\section{7.b. The sub-Tommotian unconformity}

Previous craton-wide correlations require that unconformities in Proterozoic-Cambrian successions of Siberia be 


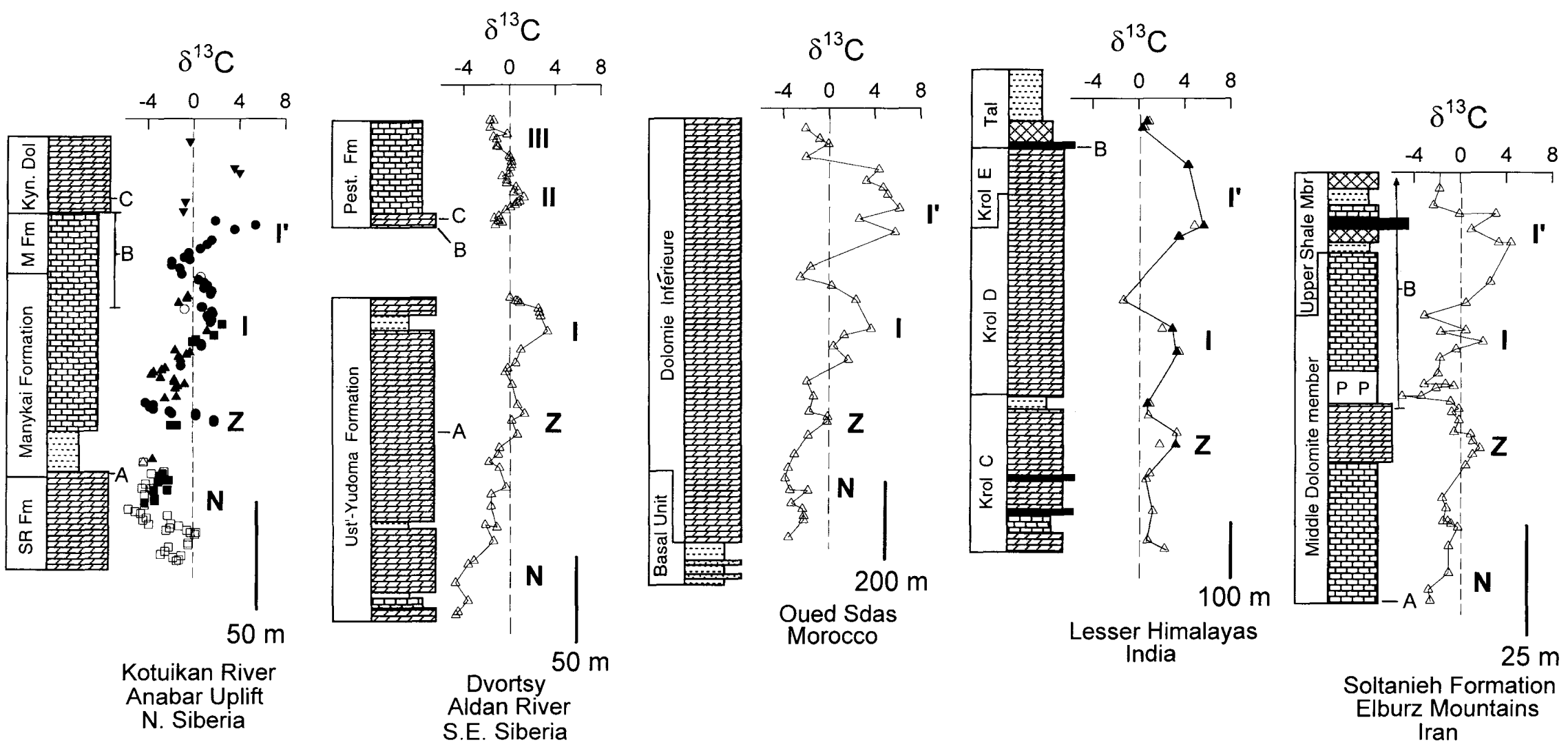

Figure 10. Chemostratigraphic correlations of the Kotuikan River and Dvortsy sections with sections in Morocco (Kirschvink et al. 1991), India (Aharon, Schidlowski \& Singh, 1987), and Iran (Brasier et al. 1990). The sub-Tommotian unconformity at Dvortsy is shown as a break in section that spans the interval from the negative excursion above Peak I to a point above the peak here designated I'. A = first appearance of Nemakit-Daldynian (A. trisulcatus Zone) faunas; B = first appearance of 'basal Tommotian' faunas; $\mathrm{C}=$ first appearance of Burithes distortus. 
diachronous among regions. While this is by no means unreasonable, the correlations advocated here encourage a different picture of earliest Cambrian tectonics on the Siberian platform. Unconformities at the Manykai/Medvezhya and Kessyusa/Erkeket boundaries record two distinct regional hiatuses of relatively short duration within the longer time interval encompassed by the Ust'-Yudoma/Pestrotsvet (sub-Tommotian) unconformity in southeastern Siberia.

In our preferred correlation, the unconformity between the Ust'-Yudoma and Pestrotsvet formations corresponds in time to a section of rocks minimally $48 \mathrm{~m}$ thick in the Kotuikan River section. Correlation of the Anabar succession with sections that contain volcanic rocks dated by $\mathrm{U}-\mathrm{Pb}$ geochronometry (Bowring et al. 1993), thus, permits us to estimate the duration of the sub-Tommotian hiatus in southeastern Siberia. As noted above, the beginning of Manykai deposition correlates bio- and chemostratigraphically with the lower Kessyusa Formation in the Olenek Uplift (Knoll et al. 1995a); a basal Kessyusa volcanic breccia has a radiometric age of $543.9 \pm 0.3 \mathrm{Ma}$ (Bowring et al. 1993). Rhyolite cobbles beneath Tommotian strata assigned to the $D$. regularis Zone (Repina et al. 1974) in the nearby Kharaulakh Mountains are 534.6 \pm 0.5 Ma old (Bowring et al. 1993). Isachsen et al. (1994) further considered the stratigraphic position of an ash bed in New Brunswick dated at $530.7 \pm 0.9 \mathrm{Ma}$ to be sub-Tommotian. This is consistent with the observation that the 535-Ma-old rhyolites in the Kharaulakh Mountains were deposited, eroded, and redeposited as cobbles before Tommotian transgression, suggesting that the Tommotian Stage began $c .530-535 \mathrm{Ma}$ ago.

Taken together, radiometric data suggest that the $114 \mathrm{~m}$ interval running from the base of the Manykai Formation to the $27 \mathrm{~m}$ level of the Medvezhya Formation lasted 8-14 Ma. The portion of this succession corresponding to the sub-Tommotian unconformity constitutes $42 \%$ of the total section. Recognizing potential problems of equating sediment thickness with time (Sadler, 1981), this suggests that the time interval represented at the sub-Tommotian unconformity in southeastern Siberia is on the order of several Ma. This estimate is probably conservative because the unconformity at the Manykai/Medvezhya boundary may, itself, mark a significant hiatus.

The summary point is that the unconformity beneath the Tommotian in southeastern Siberia represents a time interval whose duration is minimally a significant fraction of and possibly as long as the Tommotian Stage itself.

\section{7.c. Chemostratigraphy}

Kotuikan data suggest that a pronounced C-isotopic excursion immediately preceded the beginning of the Tommotian age, but that it was not Peak I recorded at Dvortsy. The sub-Tommotian excursion identified here has a much greater amplitude, indicating a distinctive biogeochemical event likely to be recorded globally.
Indeed, Early Cambrian isotopic peaks comparable in magnitude to that seen in the upper Kotuikan succession have been documented in Morocco (Tucker, 1986; Magaritz et al. 1991), India (Aharon, Schidlowski \& Singh, 1987), and Iran (Brasier et al. 1990) - southeastern Siberia is unusual in lacking a comparable $\mathrm{C}$-isotopic excursion.

Our preferred intercontinental correlations are shown in Figure 10. While we suggest that the major peaks and troughs are correlative, we acknowledge that sequence stratigraphy, biostratigraphic data and radiometric analyses of high-precision will be necessary to verify more detailed correlations. Kotuikan results also support the view that $\mathrm{Sr}$-isotopic data provide important constraints on earliest Cambrian correlation (Derry et al. 1994); however, the available data base remains small.

\section{7.d. Palaeobiological implications}

As noted above, the massed first appearance of many invertebrate taxa above the sub-Tommotian (prePestrotsvet) unconformity in southeastern Siberia has long been cause for concern among both biostratigraphers and evolutionary palaeobiologists. Kotuikan data support the hypothesis that these regional first appearances are controlled by the dynamics of regional sedimentation and do not record an evolutionary burst (Landing, 1994). If so, the Cambrian diversification of animals entered its explosive phase not at the beginning of the Tommotian, as generally accepted, but several million years earlier.

At the species level, the pattern of animal diversification through the Nemakit-Daldynian and early Tommotian ages is cumulative. Such a pattern of faunal addition without replacement lasting for more than ten million years is unusual in a Phanerozoic record more generally marked by faunal overturn every five to seven million years (see, e.g. Brett \& Baird, 1990; Morris et al. 1995). This may provide evidence that Early Cambrian ecosystems were relatively 'empty' and, therefore, tolerant of new variants or migrants.

\section{Conclusion}

The western Anabar and other Siberian sections provide an illuminating case study of how sequence stratigraphy, biostratigraphy, chemostratigraphy and geochronometry can be combined to achieve high resolution in the correlation of events and strata near the Proterozoic-Cambrian boundary. The inference that several million years go unrecorded by rocks at the sub-Tommotian unconformity in southeastern Siberia highlights the potential of integrated stratigraphic studies in ordering the biological events that gave rise to Cambrian diversity.

Acknowledgements. Samples for isotopic analysis were collected during a joint US-Russian expedition to the Anabar region in 1992. We thank V. N. Sergeev and P. Yu. Petrov for help in the field, J. Milder and R. Pflaum for laboratory support, 
A. Yu. Rozanov for helpful discussions of biostratigraphy, and M. Brasier for comments on the manuscript. This research was supported in part by NASA Grant NAGW-893 (to AHK), NSF Grant EAR-9086119 (To JPG), NSF Grant EAR-9118628 (to SBJ) and ISF Grant MLO-000 and ISF/Russian Government Grant MLO-300 (to MAS).

\section{References}

Aharon, P., Schidlowski, M. \& Singh, I. B. 1987. Chronostratigraphic markers in the end-Precambrian isotope record of the Lesser Himalaya. Nature 327, 699-702.

Bertrand-Sarfati, J., Moussine-Pouchkine, A., Amard, B. \& AIt KaCl Ahmed, A. 1995. First Ediacaran fauna found in western Africa and evidence for an early Cambrian glaciation. Geology 23, 133-6.

Bowring, S. A., Grotzinger, J. P., Isachsen, C. E., Knoll, A. H., Pelechaty, S. M. \& Kolosov, P. 1993. Calibrating rates of Early Cambrian evolution. Science 261, 1293-8.

Brasier, M. D., Khomentovsky, V. V. \& Corfield, R. M. 1993. Stable isotopic calibration of the earliest skeletal fossil assemblages in eastern Siberia (PrecambrianCambrian boundary). Terra Nova 5, 225-32.

Brasier, M. D., Magaritz, M., Corfield, R., Luo Huilin, Wu Xiche, Jiang Zhiwen, Hamdi, B., He Tinggui \& Fraser, A. G. 1990. The carbon- and oxygen-isotope record of the Precambrian-Cambrian boundary interval in China and Iran and their correlation. Geological Magazine 127, 319-32.

Brasier, M., Cowie, J. \& Taylor, M. 1994. Decision on the Precambrian-Cambrian boundary stratotype. Episodes 17, 3-8.

Brasier, M. D., Corfield, R. M., Derry, L. A., Rozanov, A. Yu. \& Zhuravlev, A. YU. 1994a. Multiple $\delta^{13} \mathrm{C}$ excursions spanning the Cambrian explosion to the Botomian crisis in Siberia. Geology 22, 455-8.

Brasier, M. D., Rozanov, A. Yu., Zhuravlev, A. Yu., Corfield, R. M. \& Derry, L. A. 1994b. A carbon isotope reference scale for the Lower Cambrian Series in Siberia and its significance. Geological Magazine 131, 767-83.

BRETT, C. R. \& BAIRD, G. C. 1990. A temporal hierarchy of paleoecologic processes within a Middle Devonian epeiric sea. Paleontological Society Special Publication 5, 18-209.

Chumakov, N. M. 1985. Glacial events of the past and their geological significance. Palaeogeography, Palaeoclimatology Palaeoecology 51, 319-46.

Crimes, T. P. 1987. Trace fossils and the PrecambrianCambrian boundary. Geological Magazine 124, 97-117.

DE RAaF, J. F. M., Boersma, J. R. \& VAN Gelder, A. 1977. Wave generated structures and sequences from a shallow marine succession, Lower Carboniferous, County Cork, Ireland. Sedimentology 24, 451-83.

Demicco, R. V. 1983. Wavy and lenticular-bedded carbonate ribbon rocks of the Upper Cambrian Conococheague Limestone, central Appalachians. Journal of Sedimentary Petrology 53, 1121-32.

Derry, L. A., Keto, L. S., Jacobsen, S. B., Knoll, A. H. \& SwETT, K. 1989. $\mathrm{Sr}$ isotopic variations in Upper Proterozoic carbonates from Svalbard and East Greenland. Geochimica et Cosmochimica Acta 53, 2331-9.

Derry, L. A., Kaufman, A. J. \& Jacobsen, S. B. 1992. Sedimentary cycling and environmental change in the Late Proterozoic: Evidence from stable and radiogenic isotopes. Geochimica et Cosmochimica Acta 56, 1317-29.

Derry, L. A., Brasier, M. D., Corfield, R. M., Rozanov, A. Yu. \& Zhuravlev, A. Yu. 1994. Sr isotopes in Lower
Cambrian carbonates from the Siberian Craton: A paleoenvironmental record during the "Cambrian explosion". Earth and Planetary Science Letters 128, 671-81.

Enos, P. \& Perkins, R. D. 1979. Evolution of Florida Bay from island stratigraphy. Bulletin, Geological Society of America 90, 59-83.

ERwin, D. H. 1993. The Great Paleozoic Crisis. New York: Columbia University Press, $327 \mathrm{pp}$.

FEdonkin, M. A. 1990. Paleoichnology of Vendian metazoa. In The Vendian System, Vol. 1: Paleontology (eds B. S. Sokolov and A. B. Iwanowski), pp. 132-7. Heidelberg: Springer-Verlag.

Fedorov, A. B. \& Shishkin, B. B. 1984. Nizhnyaya granitsa kemrbriya na severe sibirskoy platformy [Lower Cambrian boundary in the northern part of the Siberian Platform]. In Problemy yarusnogo raschleneniya sistem fanerozoya Sibiri [Problems of the stage subdivision of the Siberian Phanerozoic], pp. 5-14. Novosibirsk: Nauka.

FreEman, T. 1962. Quiet water oolites from Laguna Madre, Texas. Journal of Sedimentary Petrology 32, 475-83.

Golovanov, N. P. 1970. Stromatolity verchnedokembriiskich otlozhenii zapadnogo sklona Anabarskogo podnyatiya [Stromatolites of the Upper Precambrian deposits of the western slope of the Anabar Uplift]. In Opornii razrez verchnedokembriiskich otlozhenii zapadnogo sklona Anabarskogo podnyatniya [The Key Upper Precambrian Section in the Western Slope of the Anabar Uplift] (ed. B. V. Tkachenko), pp. 60-79. Leningrad: NIIGA.

Gorokhov, I. M., Clauer, N., TurChenko, T. L., Melnikov, N. N., Kutyavin, E. P., Pirrus, E. \& Baskakov, A. V. 1994. $\mathrm{Rb}-\mathrm{Sr}$ systematics of Vendian-Cambrian claystones from the east European Platform: implications for a multi-stage illite evolution. Chemical Geology 112, 71-89.

Grant, S. W. F. 1992. Carbon isotopic vital effects and organic diagenesis, Lower Cambrian Forteau Formation, northwest Newfoundland: Implications for $\delta^{13} \mathrm{C}$ chemostratigraphy. Geology 20, 243-6.

Grossman, E. L. 1994. The carbon and oxygen isotope record during the evolution of Pangea: Carboniferous to Triassic. Geological Society of America Special Paper 288, 207-28.

Grotzinger, J. P. 1986. Cyclicity and paleoenvironmental dynamics, Rocknest Platform, northwest Canada. Bulletin, Geological Society of America 97, 1208-31.

Grotzinger, J. P., Bowring, S. A, Saylor, B. Z. \& Kaufman, A. J. 1995. Biostratigraphic and geochronologic constraints on early animal evolution. Science 270, 598-604.

Hambrey, M. J. \& Harland, W. B. 1985. The late Proterozoic glacial era. Palaeogeography, Palaeoclimatology, Palaeoecology 51, 255-72.

HAYES, J. M. 1993. Factors controlling ${ }^{13} \mathrm{C}$ contents of sedimentary organic compounds: principles and evidence. Marine Geology 113, 111-25.

Hine, A. C., Wilber, R. J. \& Neumann, A. C. 1981. Carbonate sand-bodies along contrasting shallow-bank margins facing open seaways, northern Bahamas. Bulletin, American Association of Petroleum Geologists 65, 261-90.

HoffMAN, P. F. 1974. Shallow and deep-water stromatolites in lower Proterozoic platform-to-basin facies change, Great Slave Lake, Canada. Bulletin, American Association of Petroleum Geologists 58, 856-67.

Isachsen, C. E., Bowring, S. A., Landing, E. \& Samson, S. D. 1994. New constraint on the division of Cambrian time. Geology 22, 496-8.

Karlova, G. A. 1987. First findings of a skeletal fauna in the Turkut Formation of the Olenek Uplift. Doklady, Academy of Sciences, USSR 292, 201-5. 
Kaufman, A. J., Knoll, A. H. \& Awramik, S. M. 1992. Biostratigraphic and chemostratigraphic correlation of Neoproterozoic sedimentary successions: Upper Tindir Group, northwestern Canada, as a test case. Geology 20, 181-5.

Kaufman, A. J., Jacobsen, S. B. \& Knoll, A. H. 1993. The Vendian record of $\mathrm{Sr}$ and $\mathrm{C}$ isotopic variations in seawater: Implications for tectonics and paleoclimate. Earth and Planetary Science Letters 120, 409-30.

Kaufman, A. J. \& KnOLL, A. H. 1995. Neoproterozoic variations in the carbon isotopic composition of seawater: Stratigraphic and biogeochemical implications. Precambrian Research 73, 27-49.

Khomentovsky, V. V. 1976. Vend [Vendian]. Novosibirsk: Nauka, $271 \mathrm{pp}$.

Khomentovsky, V. V. 1986. The Vendian System of Siberia and a standard stratigraphic scale. Geological Magazine 123, 333-48.

Khomentovsky, V. V. 1990. Vendian of the Siberian Platform. In The Vendian System. Volume 2: Regional Geology (eds B. S. Sokolov and M. A. Fedonkin), pp. 102-83. Berlin: Springer-Verlag.

Khomentovsky, V. V. \& Karlova, G. A. 1992. The Precambrian-Cambrian boundary and principles of its justification in Siberia. Russian Geology and Geophysics (Translation of Geologiya i Geofizika) 33, 1-18.

Khomentovsky, V. V. \& Karlova, G. A. 1993. Biostratigraphy of the Vendian-Cambrian beds and the lower Cambrian boundary in Siberia. Geological Magazine 130, 29-45.

Khomentovsky, V. V. \& KarLova, G. A. 1994. Ecological peculiarities of the Vendian-Cambrian small shelly fauna in the Siberian Platform. Stratigraphy and Geological Correlation 2, 206-15.

Khomentovsky, V. V. \& Trofimov, V. R. 1980. Vend zapadnogo Prianabariya [Vendian of the Western Anabar area]. In Novye dannye po stratigrafii pozdnego dokembriya zapada Sibirskoi platformy i ee skladchatogo obramleniya [New Data on the Stratigraphy of the Late Precambrian of the Western Siberian Platform and its Folded Mountain Fringe] (ed. V. V. Khomentovsky), pp. 3-30. Novosibirsk: Akademiya Nauk SSSR, Sibirskoye Otdeleniye, Trudy Instituta Geologii i Geofiziki.

Khomentovsky, V. V., Valkov, A. A. \& Karlova, G. A. 1990. Novye dannye po biostratigrafii perechodnych Vend-Kembryiiskikh sloev $\mathrm{v}$ basseyne srednego techeniya r. Aldan [New data on biostratigraphy of transitional Vendian-Cambrian beds in the basin of the Aldan River middle stream]. In Pohzdniy dokembriy $i$ nizgniy Paleozoi Sibiri: Voprosy regional'noi stratigrafii [Late Precambrian and Early Paleozoic in Siberia: Problems of Regional Stratigraphy] (ed. V. V. Khomentovsky), pp. 1-57. Novosibirsk: Akademiya Nauk SSSR, Sibirskoye Otdeleniye, Trudy Instituta Geologii i Geofiziki.

KiRschVink, J. L., Magaritz, M., Ripperdan, R. L., Zhuravlev, A. Yu. \& Rozanov, A. Yu. 1991. The Precambrian/Cambrian boundary: Magnetostratigraphy and carbon isotopes resolve correlation problems between Siberia, Morocco, and South China. GSA Today 1, 69-91.

Knoll, A. H., Hayes, J. M., Kaufman, A. J., Swett, K. \& LAMBERT, I. B. 1986. Secular variation in carbon isotope ratios from Upper Proterozoic successions of Svalbard and East Greenland. Nature 321, 832-8.

Knoll, A. H., Kaufman, A. J. \& Semikhatov, M. A. 1995. The carbon-isotopic composition of Proterozoic carbonates: Riphean successions from northwestern Siberia (Anabar
Massif, Turukhansk Uplift). American Journal of Science 295, 823-50.

Knoll, A. H., Grotzinger, J. P., Kaufman, A. J. \& Kolosov, P. N. 1995a. Integrated approaches to terminal Proterozoic stratigraphy: An example from the Olenek Uplift, northeastern Siberia. Precambrian Research 73, 251-70.

Knoll, A. H., Kaufman, A. J., Semikhatov, M. A., Grotzinger, J. P. \& ADAMS, W. 1995 $b$. Sizing up the subTommotian unconformity in Siberia. Geology 23, 1139-43.

KOMAR, V. A. 1966. Stromatolity verchnedokembriiskich otlozheniy severa Sibirskoi platformy i ih stratigraficheskoe znachenie [Upper Precambrian Stromatolites in the Northern Part of the Siberian Platform and their Stratigraphic Significance]. Moscow: Trudy Geologicheskogo Instituta, Akademii Nauk SSSR, no. 154, 122 pp.

KumP, L. R. 1991. Interpreting carbon-isotope excursions: Strangelove oceans. Geology 19, 299-302.

LANDING, E. 1992. Lower Cambrian of southeastern Newfoundland: Epeirogeny and Lazarus faunas, lithofacies-biofacies linkages, and the myth of a global chronostratigraphy. In Origin and Early Evolution of the Metazoa (eds J. H. Lipps and P. W. Signor), pp. 283-310. New York: Plenum Press.

LANDING, E. 1994. Precambrian-Cambrian boundary global stratotype ratified and a new perspective of Cambrian time. Geology 22, 179-82.

LIPPS, J. H. \& SignOR, P. W. 1992. Origin and Early Evolution of the Metazoa. New York: Plenum, 570 pp.

LoNG, D. G. F. 1993. Oxygen and carbon isotopes and event stratigraphy near the Ordovician-Silurian boundary, Anticosti Island Quebec. Palaeogeography, Palaeoclimatology, Palaeoecology 104, 49-59.

LuChininA, V. A. 1989. Calcareous algae in Vendian and Lower Paleozoic stromatolites of the Siberian Platform. Himalayan Geology 13, 257-67.

Magaritz, M., Holser, W. T. \& Kirschvink, J. L. 1986. Carbon-isotope events across the Precambrian/Cambrian boundary on the Siberian Platform. Nature 320, 258-9.

Magaritz, M., Kirschvink, J. L., Latham, A. J., Zhuravlev, A. Yu. \& Rozanov, A. Yu. 1991. Precambrian/Cambrian boundary problem: Carbon isotope correlations for Vendian and Tommotian time between Siberia and Morocco. Geology 19, 847-50.

Markello, J. R. \& READ, J. F. 1981. Carbonate ramp-to-deeper shale shelf transitions of an Upper Cambrian intrashelf basin, Nolichucky Formation, southwest Virginia Appalachians. Sedimentology 28, 573-97.

Marshall, J. D. \& Middleton, P. D. 1990. Changes in marine isotopic composition and the late Ordovician glaciation. Journal of the Geological Society, London 147, 1-4.

MisSARZHEVSKY, V. V. 1989. Drevneishiye skeletniye okamenelosti i stratigrafiya pogranichnych tolshch dokembriya $i$ kembriya [Oldest Skeletal Fossils and the Stratigraphy of Precambrian/Cambrian Boundary Beds]. Moscow: Trudy Geologischeskogo Instituta, Akademii Nauk SSSR, no. 443, 237 pp.

MoczYDłowsKA, M. 1991. Acritarch biostratigraphy of the Lower Cambrian and the Precambrian-Cambrian boundary in southeastern Poland. Fossils and Strata 29, 1-127.

MoczYDŁowsKa, M. \& VIDAL, G. 1988. How old is the Tommotian? Geology 16, 166-8.

MontanEZ, I. P. 1992. Controls of eustacy and associated diagenesis on reservoir hetereogeneity in Lower Ordovician, upper Knox carbonates, Appalachians. In Paleokarst, Karst-Related Diagenesis and Reservoir Development: 
Examples from Ordovician-Devonian Age Strata of West Texas and the Mid-Continent (eds M. P. Candelaria and C. L. Reed), pp. 165-81. SEPM Permian Basin Section, Publication 92-93.

Montanez, I. P. \& OSleger, D. A. 1993. Parasequence stacking patterns, third-order accommodation events, and sequence stratigraphy of Middle to Upper Cambrian platform carbonates, Bonanza King Formation, southern Great Basin. In Carbonate Sequence Stratigraphy: Recent Developments and Applications (eds R. G. Loucks and F. R. Sarg), pp. 305-26. American Association of Petroleum Geologists Memoir no. 57.

Morris, P. J. IvanY, L. C., SCHOPF, K. M. \& BRETT, C. E. 1995. The challenge of paleoecological stasis: reassessing sources of evolutionary stability. Proceedings, National Academy of Sciences, U.S.A. 92, 11269-73.

Narbonne, G. M. \& MYrow, P. 1988. Trace fossil biostratigraphy in the Precambrian-Cambrian boundary interval. New York State Museum Bulletin 463, 72-6.

Narbonne, G. M., Myrow, P. M., Landing, E. \& Anderson, M. M. 1987. A candidate stratotype for the PrecambrianCambrian boundary, Fortune Head, Burin Peninsula, southeastern Newfoundland. Canadian Journal of Earth Sciences 24, 1277-93.

Narbonne, G. M., Kaufman, A. J. \& Knoll, A. H. 1994. Integrated chemostratigraphy and biostratigraphy of the upper Windermere Supergroup (Neoproterozoic), Mackenzie Mountains, northwestern Canada. Bulletin, Geological Society of America 106, 1281-92.

Pelechaty, S. M., Kaufman, A. J. \& Grotzinger, J. P. 1996. Evaluation of $\delta^{13} \mathrm{C}$ isotope stratigraphy for intrabasinal correlation: Vendian strata of the Olenek uplift and Kharaulakh Mountains, Siberian platform, Russia. Geological Society of America $\mathbf{1 0 8}$, in press.

Pokrovsky, B. G. \& Missarzhevsky, V. V. 1993. Izotopnaya korrelyatsiya pogranichnikh tolshch dokembrriya i kembriya sibirskoy platformy [Isotopic correlation of Precambrian and Cambrian boundary beds of the Siberian Platform]. Doklady Akademii Nauk Rossiya 329, 768-71.

PoKrovsky, B. G. \& Vinogradov, V. I. 1991. Izotopnich sostav stronstiya i ugleroda $\mathrm{v}$ verchnedokembriyskich karbonatakh zapadnogo sklona anabarskogo podnyatiya (r. Kotuikan) [Isotopic composition of strontium, oxygen, and carbon in the Upper Precambrian carbonates of the western slope of the Anabar Uplift (Kotuikan River)]. Doklady Akademii Nauk SSSR 320, 1245-50.

Pratt, L. M., Force, E. R. \& Pomerol, B. 1991. Coupled manganese and carbon-isotopic events in marine carbonates at the Cenomanian-Turonian boundary. Journal of Sedimentary Petrology 61, 370-83.

QIAN Yi \& Bengtson, S. 1989. Palaeontology and biostratigraphy of the Early Cambrian Meishucunian Stage in Yunnan Province, South China. Fossils and Strata 24, 1-156.

Read, J. F., Grotzinger, J. P., Bova, J. A. \& Koerschner, W. F. 1986. Models for generation of carbonate cycles. Geology 14, 107-10.

Repina, L. N. \& Rozanov, A. Yu. 1992. Kembriy Sibiri [The Cambrian of Siberia]. Novosibirsk: Trudy Instituta Geologii i Geofiziki SO AN SSSR, no. 788, 135 pp.

Repina, L. N., Lazarenko, N. P., Meshkova, N. P. Korshunov, V. T., Nikiforov, N. T. \& Aksarina, N. A. 1974. Biostratigrafiya $i$ fauna nizhnego kembriya Kharaulakha (Khrebet Tuora-Sis) [Biostratigraphy and fauna of the Lower Cambrian of the Kharaulakh (TuoraSis Ridge)]. Moscow: Nauka.

Rozanov, A. YU. (Ed.) 1982. Granitsa dokembriya i kembriya v geosinklinalnykh oblastyakh (Opornyi razrez Salany-Gol, $M N R)$. [Precambrian-Cambrian boundary in geosynclinal areas (the reference section of Salany-Gol, MPR)]. Moscow: Nauka, 150 pp.

Rozanov, A. YU. 1984. The Precambrian/Cambrian boundary in Siberia. Episodes 7, 20-4.

Rozanov, A. Yu. \& Sokolov, B. S. 1984. Yarusnoe raschlenenie nizhnego kemryiya: Stratigrafiya [Lower Cambrian Stage Subdivision: Stratigraphy]. Moscow: Nauka, 184 pp.

Rozanov, A. Yu., Volkova, N. A., Voronova, L. C., Krylov, I. N., Keller, B. M., Korolyuk, I. K., Lendzion, K., Michniak, R., Pykhova, N. G. \& Sidorov, A. D. 1969. The Tommotian Stage and the Cambrian Lower Boundary Problem. New Delhi: Amerind Publishing Company (1981 translation), $359 \mathrm{pp}$

SADLER, P. M. 1981. Sediment accumulation rates and the completeness of stratigraphic sections. Journal of Geology $\mathbf{8 9}$, 569-84.

SARG, J. F. 1988. Carbonate sequence stratigraphy. In Sea-Level Changes: An Integrated Approach (eds C. K. Wilgus, B. S. Hastings, C. G. S. C. Kendall, H. W. Posamentier, C. A. Ross and J. C. Van Waggoner), pp. 155-82. SEPM Special Publication no. 42.

SAVITSKY, V. E. 1962. O sootnosheniy kembriya i verchnego dokembriya Anabarskogo shchita [On the relationships between the Cambrian and Upper Precambrian on the Anabar shield]. In Sovetschanie po stratigrafii otlozheniy pozdnego dokembriya Sibiri i Dal'nego Vostoka [Meeting on the Stratigraphy of Late Precambrian Deposits on Siberia and the Far East] (ed. B. S. Sokolov), pp. 53-4. Novosibirsk: Nauka.

SAVITSKY, V. E. 1975. Problema nizhney granitsy kembriya na Sibirskoy platforme i nemakit-daldynskiy gorizont [Problem of the lower Cambrian boundary in the Siberian Platform and Nemakit-Daldynian Horizon]. In Analogi Vendskogo kompleksa $v$ Sibiri (Analogues of the Vendian Complex in Siberia), pp. 43-61. Moscow: Nauka.

SCholle, P. A. 1995. Carbon and sulfur isotope stratigraphy of the Permian and adjacent intervals. In The Permian of Northern Pangea, Volume 1: Paleogeography, Paleoclimates, Stratigraphy (eds T. M. Peryt and D. S. Ulmer-Scholle), pp. 133-49. New York: Springer-Verlag.

Semikhatov, M. A., Komar, V. A. \& Serebryakov, S. N. 1970. Yudomskiy kompleks stratotipicheskoy mestnosti [The Yudomian Complex of the Stratotype Area]. Moscow: Trudy Geologischeskogo Instituta, Akademii Nauk SSSR, no. 210,207 pp.

Semikhatov, M. A. \& Serebryakov, S. N. 1983. Sibirsky gipostratotip rifeya [The Siberian Hypostratotype of the Riphean]. Moscow: Trudy Geologicheskogo Instituta, Akademii Nauk SSSR, no. 367, 224 pp.

SHAw, A. B. 1964. Time in Stratigraphy. New York: McGraw-Hill, 365 pp.

SHISHKIN, B. B. 1978. K voprosu o stratigraficheskom raschlenenii verknedokembriiskikh obrazovaniy na territorii zapadnogo Prianabarya (On the stratigraphic subdivision of the Upper Precambrian deposits on the Western Anabar territory). In Stratigraphiya dokembriya i nizhnego kembriya vostoka Sibirskoi platformy [Precambrian and Cambrian stratigraphy of the Eastern Siberian Platform], pp. 66-75. Yakutsk: Nauka.

Shpunt, B. R., Shapovalova, Y. G. \& Shamshina, E. A. 1982. Pozdniy dokembriy severa Sibirskoi platformy [Late Precambrian on the Northern Siberian Platform]. Novosibirsk: Nauka, 225 pp. 
SLOSS, L. L. 1963. Sequences in the cratonic interior of North America. Bulletin, Geological Society of America 74, 93-114.

Smith, L. H., KaufMan, A. J., KNoll, A. H. \& LinK, P. K. 1994. Chemostratigraphy of predominantly siliciclastic Neoproterozoic successions: a case study of the Pocatello Formation and Lower Brigham Group, Idaho, USA. Geological Magazine 131, 301-14.

TuCKer, M. E. 1986. Carbon isotope excursions in Precambrian/Cambrian boundary beds, Morocco. Nature 319, 48-50.

VEIZER, J. 1983. Chemical diagenesis of carbonates: Theory and application of trace element technique. In Stable Isotopes in Sedimentary Geology (eds M. A. Arthur, T. F. Anderson, I. R. Kaplan, J. Veizer and L. S. Land), S.E.P.M. Short Course 10, 3-1-3-100.

Vidal, G., MoczydłowsKa, M. \& Rudavskaya, V. R. 1995. Constraints on the early Cambrian radiation and correlation of the Tommotian and Nemakit-Daldynian regional stages of eastern Siberia. Journal of the Geological Society, London 152, 499-510.

Volkova, N. A. 1968. Akritarkhi dokembrijskikh i nizhnekembrijskikh otlozhenij Estonii [Acritarchs from the Precambrian and Cambrian of Estonia]. In Problematiki pogranichnykh sloev rifeya i kembriya Russkoj platformy, Urala $i$ Khzakhstana [Problematics of Riphean and Cambrian layers of the Russian Platform, Urals and Kazakhstan] (eds N. A. Volkova, Z. A. Zhuraleva, V. E. Zabrodin and B. Sh. Klinger), pp. 8-36. Moscow: Nauka.

Volkova, N. A., Kir'Yanov, V. V., Piscun, L. V.,
Pashkyavichene, L. T. \& Jankauskas, T. V. 1979. Rastitel'nye mikrofossilii [Microflora]. In Paleontologiya verkhnedokembriiskikh $i$ kembriiskikh otlozhenii Vostochno-Europejskoi plarformy [Upper Precambrian and Cambrian paleontology of the East European Platform] (eds B. M. Keller and A. Yu. Rozanov), pp. 4-38. Moscow: Nauka.

Volkova, N. A., Kir'Yanov, V. V., Pyatiletov, V. G., Rudavskaya, V. A., Treshchetenkova, A. A., Faizulina, E. K. \& JANKAUSKAS, T. V. 1980. Mikrofossilii verkhnego dokembriya sibirskoy platformy [Upper Precambrian microfossils of the Siberian Platform]. Izvestiya Akademikii Nauk SSSR, Seriya Geologicheskaya 1, 23-9.

Volkova, N. A., KiR'Yanov, V. V., Piscun, L. V., Pashkyavichene, L. T. \& Jankauskas, T. V. 1983. Plant microfossils. In Upper Precambrian and Cambrian Palaeontoloty of the East-European Platform (eds A. Urbanek and A. Yu. Rozanov), pp. 7-46. Warszawa: Wydawnictwa Geologiczne.

Wang Kun, Orth, C. J., Attrep, M., Chatterton, B. D. E., WANG XIAOFENG \& Li Ji-Jin. 1993. The great latest Ordovician extinction on the South China Plate: Chemostratigraphic studies of the Ordovician-Silurian boundary interval on the Yangtze Platform. Palaeogeography, Palaeoclimatology, Palaeoecology 104, 61-79.

ZhuRAVLeVA, Z. A. \& Komar, V. A. 1962. K stratigraphii rifeya (siniya) Anabarskogo massiva [On the Riphean (Sinian) stratigraphy of the Anabar Massif]. Doklady Akademii Nauk SSSR 144, 197-200. 